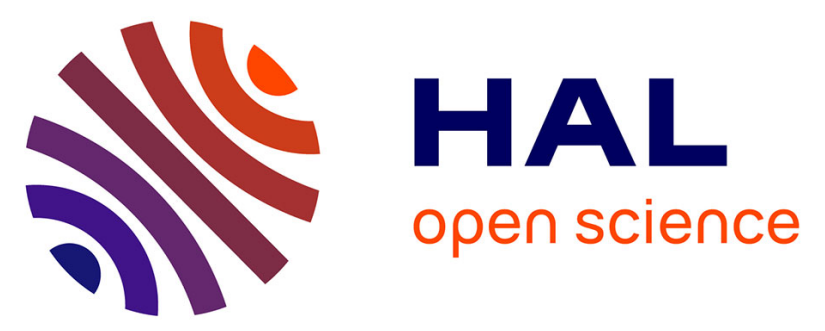

\title{
Quantifying uncertainty in estimates of mineral dust flux: An intercomparison of model performance over the Bodélé Depression, northern Chad
}

Martin C. Todd, Diana Bou Karam, C. Cavazos, Christel Bouet, B. Heinold, J.M. Baldasano, Guy Cautenet, I. Koren, C. Perez, Fabien Solmon, et al.

\section{To cite this version:}

Martin C. Todd, Diana Bou Karam, C. Cavazos, Christel Bouet, B. Heinold, et al.. Quantifying uncertainty in estimates of mineral dust flux: An intercomparison of model performance over the Bodélé Depression, northern Chad. Journal of Geophysical Research: Atmospheres, 2008, 113 (D24), pp.D24107. 10.1029/2008JD010476 . hal-00348062

\section{HAL Id: hal-00348062 https://hal.science/hal-00348062}

Submitted on 9 Mar 2016

HAL is a multi-disciplinary open access archive for the deposit and dissemination of scientific research documents, whether they are published or not. The documents may come from teaching and research institutions in France or abroad, or from public or private research centers.
L'archive ouverte pluridisciplinaire HAL, est destinée au dépôt et à la diffusion de documents scientifiques de niveau recherche, publiés ou non, émanant des établissements d'enseignement et de recherche français ou étrangers, des laboratoires publics ou privés. 


\title{
Quantifying uncertainty in estimates of mineral dust flux: An intercomparison of model performance over the Bodélé Depression, northern Chad
}

\author{
M. C. Todd, ${ }^{1}$ D. Bou Karam,${ }^{2}$ C. Cavazos,${ }^{1}$ C. Bouet,${ }^{3}$ B. Heinold,${ }^{4}$ J. M. Baldasano,,${ }^{5,6}$ \\ G. Cautenet, ${ }^{3}$ I. Koren, ${ }^{7}$ C. Perez, ${ }^{5}$ F. Solmon, ${ }^{8}$ I. Tegen, ${ }^{4}$ P. Tulet, ${ }^{9}$ R. Washington, ${ }^{10}$ \\ and A. Zakey ${ }^{11}$
}

Received 22 May 2008; revised 16 September 2008; accepted 18 September 2008; published 17 December 2008.

[1] Mineral dust aerosols play an important role in the climate system. Coupled climateaerosol models are an important tool with which to quantify dust fluxes and the associated climate impact. Over the last decade or more, numerous models have been developed, both global and regional, but to date, there have been few attempts to compare the performance of these models. In this paper a comparison of five regional atmospheric models with dust modules is made, in terms of their simulation of meteorology, dust emission and transport. The intercomparison focuses on a 3-day dust event over the Bodélé depression in northern Chad, the world's single most important dust source. Simulations are compared to satellite data and in situ observations from the Bodélé Dust Experiment (BoDEx 2005). Overall, the models reproduce many of the key features of the meteorology and the large dust plumes that occur over the study domain. However, there is at least an order of magnitude range in model estimates of key quantities including dust concentration, dust burden, dust flux, and aerosol optical thickness. As such, there remains considerable uncertainty in model estimates of the dust cycle and its interaction with climate. This paper discusses the issues associated with partitioning various sources of model uncertainty.

Citation: Todd, M. C., et al. (2008), Quantifying uncertainty in estimates of mineral dust flux: An intercomparison of model performance over the Bodélé Depression, northern Chad, J. Geophys. Res., 113, D24107, doi:10.1029/2008JD010476.

\section{Introduction}

[2] Mineral dust aerosols are an important component of the Earth's climate system by virtue of (1) their direct influence on the Earth's radiation budget through absorption and scattering of solar and terrestrial radiation, (2) the indirect effect through modification of cloud properties, (3) the effect of items 1 and 2 on atmospheric stability

\footnotetext{
${ }^{1}$ Department of Geography, University College London, London, UK.

${ }^{2}$ Service d'Aéronomie, Institut Pierre-Simon Laplace, Université Pierre et Marie Curie, Paris, France.

${ }^{3}$ Laboratoire de Météorologie Physique, Université Blaise Pascal, Aubière, France.

${ }^{4}$ Leibniz Institute for Tropospheric Research, Leipzig, Germany.

${ }^{5}$ Earth Sciences Department, Barcelona Supercomputing Center, Barcelona, Spain.

${ }^{6}$ Laboratory of Environmental Modelling, Polytechnic University of Catalonia, Barcelona, Spain.

${ }^{7}$ Weizmann Institute, Rehovot, Israel.

${ }^{8}$ Laboratoire d' Aérologie, Université Paul Sabatier, Toulouse, France.

${ }^{9}$ GMEI, CNRM, Météo France, Toulouse, France.

${ }^{10}$ Oxford Centre for the Environment, University of Oxford, Oxford, UK.

${ }^{11}$ Abdus Salam International Centre for Theoretical Physics, Trieste, Italy.

Copyright 2008 by the American Geophysical Union. 0148-0227/08/2008JD010476
}

and circulation, and (4) their role in terrestrial and oceanic biogeochemical cycles. Despite increased research into these processes in recent decades, aerosols remain one of the greatest sources of uncertainty in interpretation and projection of past and future climate change [Forster et al., 2007]. The distribution, properties and climate impact of mineral dust in particular is relatively poorly understood, despite evidence that the radiative impact may be comparable to that of anthropogenic sulphate aerosols [Forster et al., 2007]. In many regions mineral dust is the biggest contribution to atmospheric optical thickness [Tegen et al., 1997], and evidence exists of increasing dust production in recent decades [Goudie and Middleton, 1992; Prospero and Lamb, 2003].

[3] Observations and simulations have demonstrated that in regions of high dust emission such as North Africa dust aerosols strongly influence surface and tropospheric radiation budgets and consequently the atmospheric circulation [e.g., Miller and Tegen, 1998; Haywood et al., 2005; Grini et al., 2006; Mahowald et al., 2006; Yoshioka et al., 2007]. It is likely that numerical weather prediction models benefit from inclusion of dust aerosols in these regions [e.g., Pérez et al., 2006a; Rodwell and Jung, 2008]. As a result, in recent years a number of experimental and operational dust forecast systems have been developed at institutes around the world, for example, the Navy Aerosol Analysis and 
(a)

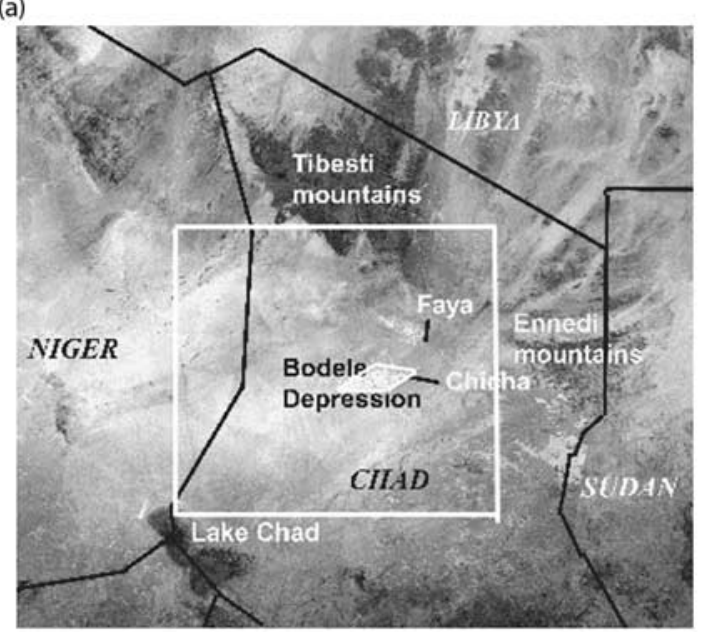

(b)

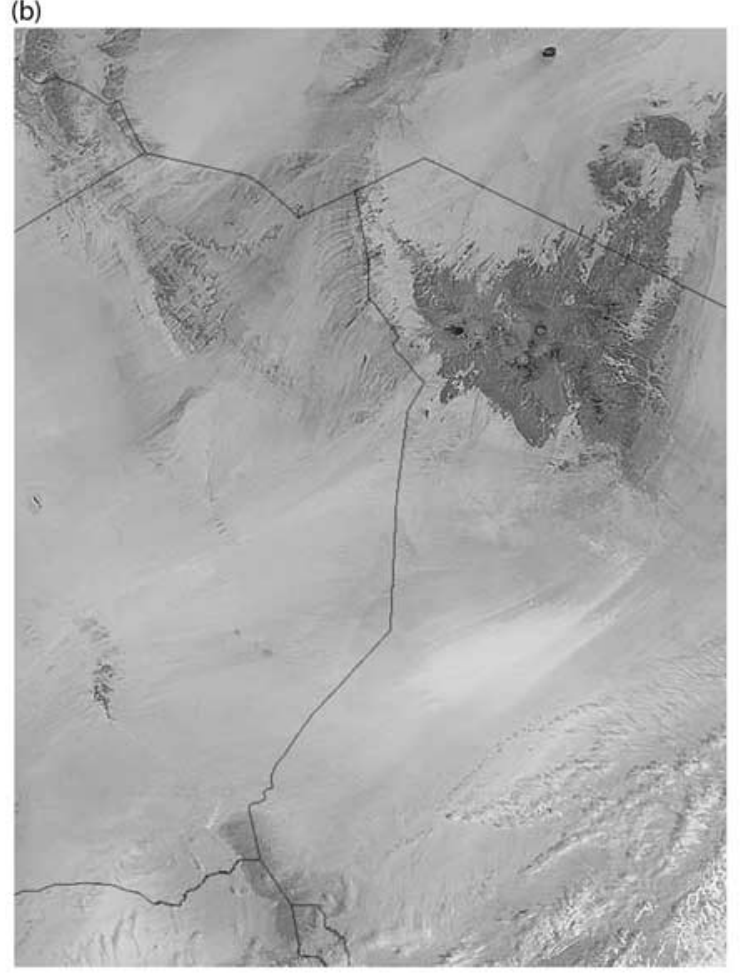

Figure 1. (a) MODIS channel 4 surface reflectance (8-day composite, 27 February 2005 to 6 March 2005). (b) MODIS true color composite (channels 3, 4, and 1) image for 0945 UTC 11 March 2005. The location of the BoDEx 2005 field site at Chicha $\left(16.9^{\circ} \mathrm{N}, 18.5^{\circ} \mathrm{E}\right)$ and other political and geographical features are indicated. In Figure 1a the domains over which the model quantities are derived in Tables $1-5$ are indicated as white lines. The smaller of these encompasses the area of exposed diatomite sediment within the Bodélé Depression, visible as the bright surface immediately east of Chicha.

Prediction System (NAAPS), the Global and regional Earthsystem (Atmosphere) Monitoring using Satellite and in situ data (GEMS) at the European Centre for Medium-range Weather Forecasts [Morcrette et al., 2007], and the Dust REgional Atmospheric Model (DREAM) [Nickovic et al.,
2001]. At the same time, inclusion of dust aerosols is an important step in the further development of climate and Earth system models. Such dust models can make an important contribution to understanding the role of dust in the climate system. At present, however, there exists considerable uncertainty in model estimates of dust emission and fluxes at global [Zender et al., 2004] and regional scales [Uno et al., 2006]. Therefore, it is important that numerical simulation of dust processes in weather forecast and climate models is improved. A common understanding of model behavior will help reduce this uncertainty in the future and help inform the interpretation of dust forecasts.

[4] It is widely recognized from analysis of satellite data that dust emission occurs primarily in a relatively small number of preferential source regions, mostly located in the world's arid zones, notably the Sahara desert [Herman et al. 1997; Prospero et al., 2002; Torres et al., 2002; Washington et al., 2003; Zhang and Christopher, 2003]. Of these source regions the Bodélé depression, in northern Chad is the region with consistently the highest mineral dust aerosol loadings. This region is, therefore, the single most significant dust source, and has been referred to as the "dustiest place on Earth" [Washington et al., 2003]. Unlike other regions of the Sahara it is a major dust source throughout the year. The Bodéle depression is the lowest part of the paleo-lake basin Mega-Chad. The lake last dried up some 5000 years BP [Drake and Bristow, 2006] leaving diatomite sediments exposed at the surface. Today, these sediments cover an area of $\sim 10,800 \mathrm{~km}^{2}$ centered near $17^{\circ} \mathrm{N}, 18^{\circ} \mathrm{E}$, clearly apparent from satellite imagery (Figure 1a). The high dust emission from the region is due to the erosive action on these readily erodible sediments of locally strong winds associated with the Bodélé Low Level Jet (LLJ) [Washington and Todd, 2005; Washington et al., 2006; Todd et al., 2007]. This phenomenon is described in more detail in section 3.1 but is associated with the channeling effects of the Tibesti and Ennedi mountains that rise around $2600 \mathrm{~m}$ to the north, and $1000 \mathrm{~m}$ to the east, respectively, above the Bodélé depression (Figures 1a and 2b). Thus, the coincidence of the LLJ and diatomite sediment produces extensive dust plumes, which extend as singular features up to $1000 \mathrm{~km}$ downwind (Figure 1b) and occur with remarkable frequency, around 100 times per year [Koren and Kaufman, 2004; Washington et al., 2006]. Koren et al. [2006] estimate that about half of all mineral dust transported from North Africa to South America originates in the Bodélé depression.

[5] A key requirement of dust models, therefore, is that they simulate accurately the dust flux from the Bodélé depression. This represents a key test of model fidelity. This paper presents the results of an intercomparison of model simulations of a large dust event from the Bodélé over 3 days from 10 to 12 March 2005, coincident with the first in situ data acquired from the region during the Bodélé Dust Experiment (BoDEx 2005) [Washington et al., 2006; Todd et al., 2007; Warren et al., 2007] (http://www.geog. ox.ac.uk/research/climate/projects/bodex/). The paper aims to (1) determine the degree of uncertainty in estimates of dust emission and transport from a range of model simulations, (2) highlight the sources of uncertainty in these estimates, and (3) point to the key foci for future research to constrain this uncertainty. The aim is not to rank the model 
(a)

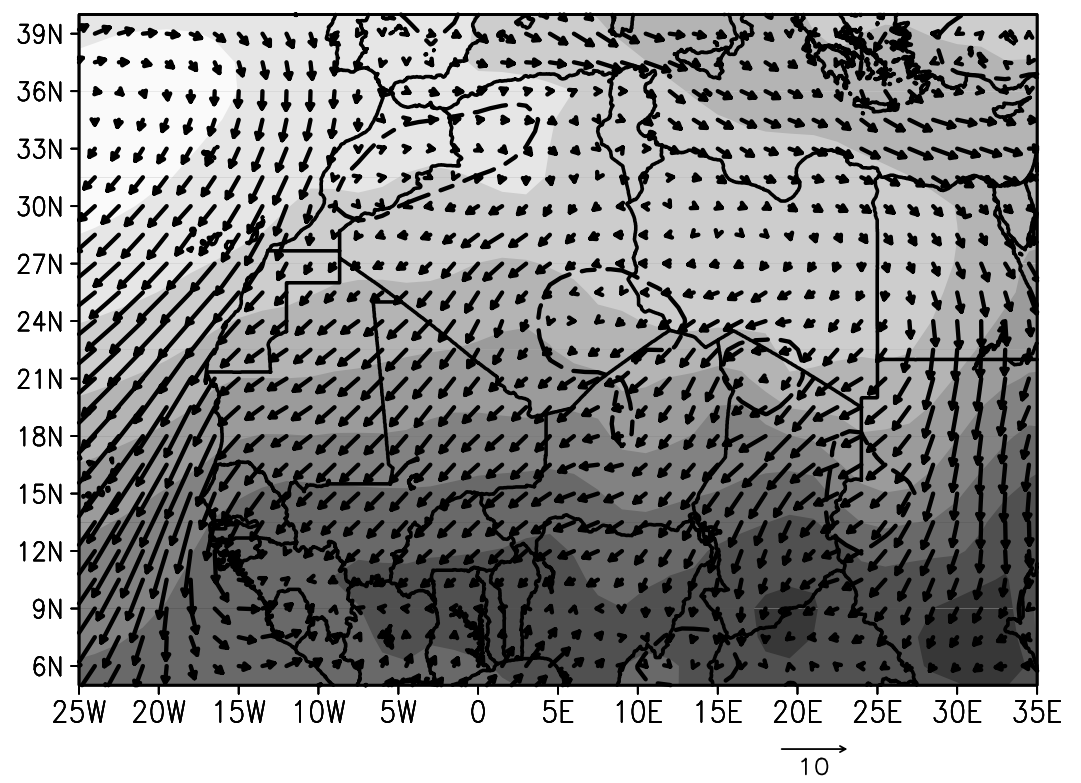

10081010101210141016101810201022

(b)

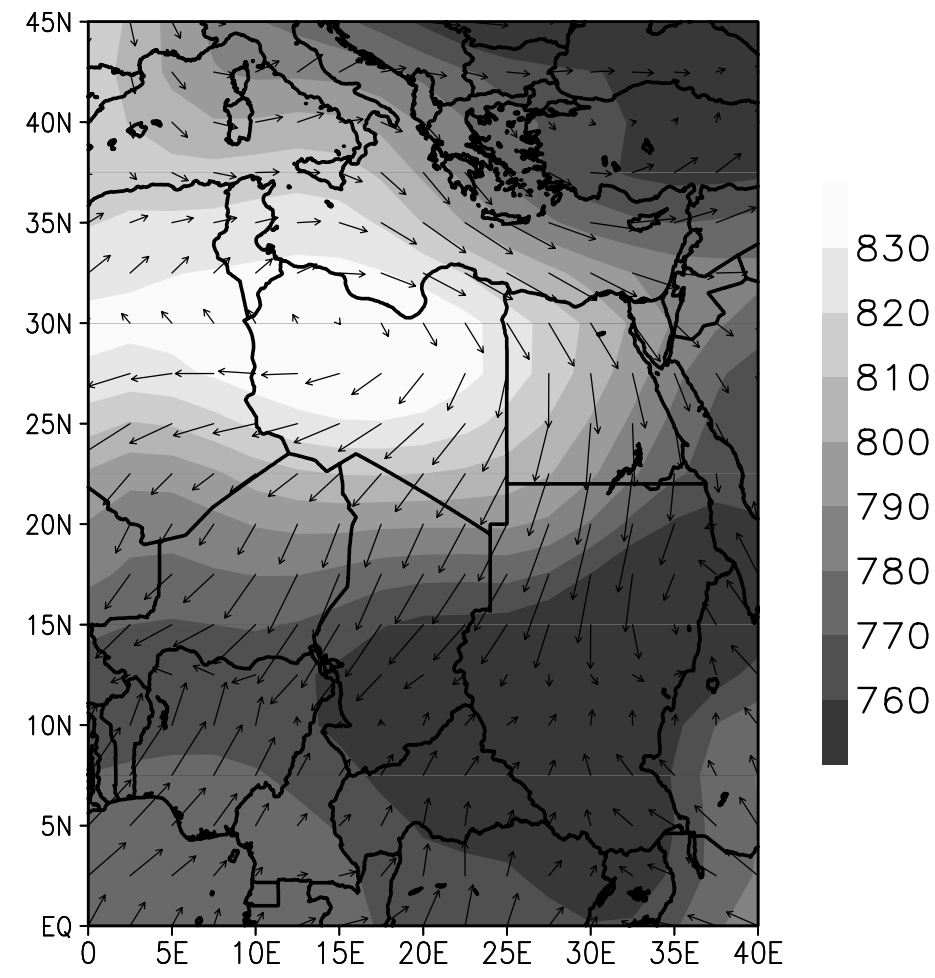

Figure 2. (a) Mean (1979-2001) winter JFM season sea level pressure (SLP in hPa, shading) and $925 \mathrm{hPa}$ wind (vectors); surface 1000-m contour is marked with dotted line. (b) Mean $925 \mathrm{hPa}$ height (gpm, shading) and wind ( $\mathrm{m} \mathrm{s}^{-1}$ vectors) for 10-12 March 2005. Data for Figure 2a are from ERA-40 reanalysis, and data for Figure $2 \mathrm{~b}$ are from NCEP reanalysis.

performance but rather highlight the degree of uncertainty in various aspects of model simulation.

[6] The paper is organized as follows. Section 2 provides a description of the models and experimental configuration, as well as the observational data used for model evaluation. In section 3, an overview of the meteorology of the study region of particular relevance to dust emission is provided. Section 4 includes the primary results of the model inter- 
Table 1. Dust Model Results for Mean 10-m Height Wind Speed Over Period 10-12 March 2005 ${ }^{\mathrm{a}}$

\begin{tabular}{lcccccc}
\hline \multicolumn{1}{c}{ Averaging Area } & Observations & RegCM3 & LM-MUSCAT & Meso-NH & RAMS-DPM & DREAM \\
\hline Chicha & 13.5 & 8.82 & 8.42 & 9.62 & 11.73 \\
Area $<250 \mathrm{~m}$ height & N/A & 8.92 & 8.08 & 9.19 & 11.15 \\
$14^{\circ} \mathrm{E}-21^{\circ} \mathrm{E}, 14^{\circ} \mathrm{N}-21^{\circ} \mathrm{N}$ & N/A & 6.71 & 6.27 & 6.0 & 5.98 \\
\hline
\end{tabular}

${ }^{\mathrm{a}}$ Wind speed given in $\mathrm{m} \mathrm{s}^{-1}$. N/A denotes not available.

comparison subdivided into sections on meteorology and various components of the dust cycle. Discussion and conclusions follow in section 5 .

\section{Data and Methods}

\subsection{Dust Models}

[7] Kinne et al. [2003] report that many global dust models underestimate dust emission from key source regions like the Bodélé. In this study we analyze the results of dust flux estimates from dust models configured at the regional scale more appropriate to simulation of this source region. We obtained results from five dust models summarized in Appendix A, Table A1. All the models in this study except DREAM utilize essentially the same dust emission scheme originally developed by Marticorena and Bergametti [1995]. In this scheme size resolved dust emission $(F)$ is based on parameterizations of soil aggregate saltation and sandblasting processes, in which saltating sand size soil aggregates break soil into smaller particles which are released into the atmosphere (equation (1)). Saltation occurs when the wind friction velocity exceeds a minimum threshold $\left(u_{* t r}\right)$, itself a function of soil particle size, soil particle density, surface roughness and soil moisture. The size resolved horizontal saltation flux is then largely a function of the third power of wind friction velocity. Finally, the vertical dust flux into the atmosphere results from the sandblasting effect of saltation and is a function of the kinetic energy of the aggregate (proportional to the horizontal flux) and the soil binding energies.

$$
\begin{aligned}
F= & \alpha \frac{\rho_{a}}{g} u_{*}^{3} \sum_{i}\left[\left(1+\frac{u_{* t r i}}{u *}\right)\left(1-\frac{u_{*_{t r i}}^{2}}{u_{*}^{2}}\right) S_{i}\right] \\
& \cdot\left(1-A_{\text {veg }}\right)\left(1-A_{\text {snow }}\right),
\end{aligned}
$$

where $\alpha$ is the ratio between the vertical dust flux and the horizontal saltation flux (the sandblasting efficiency), and the rest of the right hand side of equation (1) describes the horizontal saltation flux in which $\rho_{a}$ is the air density, $g$ is the gravitational constant, $u *$ is the surface friction velocity, $u_{* t r i}$ is the threshold friction velocity for size fraction $i, S_{i}$ is the relative surface area covered by particles of size fraction $i, A_{v e g}$ is the part of the area covered by vegetation, and $A_{\text {snow }}$ is the part of the area covered by snow [from Tegen et al., 2006]. The $\alpha$ parameter expresses the relationship between the kinetic energy of the saltating aggregate impacting on the soil and the binding strength of the soil, but the method by which the values are determined varies between the models. Table A1 in Appendix A shows the values of $\alpha$ where available. In RegCM3 the $\alpha$ parameter is calculated explicitly as a function of the kinetic energy of the saltating particles (proportional to the mass flux) and the soil binding energies of the soil particles from Alfaro and Gomes [2001], and as such is a complex function of friction velocity, soil texture and emission mode size. The values of $\alpha$ in the RAMS-DPM are calculated from the empirical relation deduced from the measurements of Gillette [1979], and are a function of soil texture, specifically clay content, where higher soil clay content is associated with higher values of $\alpha$. In LM-MUSCAT the single $\alpha$ parameter was actually "tuned" for these particular experiments by optimizing to ensure good match between modeled and observed aerosol optical thickness (AOT) during BoDEx itself. In Meso-NH a single $\alpha$ parameter is used on the basis of that utilized in global simulations by Zender et al. [2003]. This $\alpha$ value provided acceptable estimates of AOT by Meso-NH compared to observations for model runs over West Africa at relatively low resolution $(40-60 \mathrm{~km})$. Interestingly, P. Tulet (personal communication, 2008) notes that the $\alpha$ values here may be too high by about $33 \%$, as subsequent model calibration experiments suggest a dependence on model resolution, an issue considered further in section 5. The values of $\alpha$ used in the models here (Table A1 in Appendix A) range over $\sim 3$ orders of magnitude which is similar to the range of values observed by Gillette [1979] associated with variations in soil clay content from 0 to $20 \%$. In most cases over the Sahara the clay content of the soil, like soil texture, is not well constrained [Zender et al., 2003; Tegen et al., 2006] such

\begin{tabular}{|c|c|c|c|c|}
\hline Quantity & Averaging Area & RegCM3 & LM-MUSCAT & RAMS-DPM \\
\hline \multirow[t]{3}{*}{ Peak emission (1200 UTC 10 March 2005) } & Chicha & $6.93 \times 10^{-4}$ & $5.92 \times 10^{-4}$ & $3.38 \times 10^{-3}$ \\
\hline & area $<250 \mathrm{~m}$ height & $9.0 \times 10^{-4}$ & $6.17 \times 10^{-4}$ & $2.58 \times 10^{-3}$ \\
\hline & $14-21^{\circ} \mathrm{E}, 14-21^{\circ} \mathrm{N}$ & $2.63 \times 10^{-4}$ & $2.58 \times 10^{-4}$ & $5.61 \times 10^{-4}$ \\
\hline \multirow[t]{3}{*}{ Mean emission (10-12 March 2005) } & Chicha & $4.1 \times 10^{-4}$ & $4.69 \times 10^{-4 b}$ & $1.38 \times 10^{-3}$ \\
\hline & area $<250 \mathrm{~m}$ height & $5.0 \times 10^{-4}$ & $5.37 \times 10^{-4 b}$ & $1.3 \times 10^{-3}$ \\
\hline & $14-21^{\circ} \mathrm{E}, 14-21^{\circ} \mathrm{N}$ & $1.39 \times 10^{-4}$ & $2.1 \times 10^{-4 b}$ & $2.81 \times 10^{-4}$ \\
\hline \multirow[t]{2}{*}{ Total emission (10-12 March 2005) } & area $<250 \mathrm{~m}$ height & 1.4 & 1.5 & 3.6 \\
\hline & $14-21^{\circ} \mathrm{E}, 14-21^{\circ} \mathrm{N}$ & 21.1 & 31.9 & 42.5 \\
\hline
\end{tabular}

Table 2. Dust Model Results for Dust Emission Rate and Total Emission From Available Models ${ }^{\mathrm{a}}$

${ }^{\mathrm{a}}$ Dust emission rate given in $\mathrm{g} \mathrm{m}^{-2} \mathrm{~s}^{-1}$; total emission given in $\mathrm{Tg}$.

${ }^{\mathrm{b}}$ Emission for LM-MUSCAT is for 1200 UTC only. 
Table 3. Dust Model Results for Mean Lowest Level Dust Concentration and Column Integrated Dust Mass Averaged Over 10-12 March $2005^{\mathrm{a}}$

\begin{tabular}{|c|c|c|c|c|c|c|}
\hline Quantity & Averaging Area & RegCM3 & LM-MUSCAT & Meso-NH & RAMS-DPM & DREAM \\
\hline Lowest level dust concentration & $\begin{array}{l}\text { Chicha } \\
\text { area }<250 \mathrm{~m} \text { height }\end{array}$ & $\begin{array}{l}3757 \\
4500\end{array}$ & $\begin{array}{l}15322 \\
15700\end{array}$ & $\begin{array}{l}26000 \\
25200\end{array}$ & $\begin{array}{l}19740 \\
26800\end{array}$ & $\begin{array}{l}2148 \\
2700\end{array}$ \\
\hline Column integrated dust mass & $\begin{array}{l}\text { Chicha } \\
\text { area }<250 \mathrm{~m} \text { height } \\
14^{\circ} \mathrm{E}-21^{\circ} \mathrm{E}, 14^{\circ} \mathrm{N}-21^{\circ} \mathrm{N}\end{array}$ & $\begin{array}{l}1.91 \\
1.57 \\
0.77\end{array}$ & $\begin{array}{l}11.57 \\
11.58 \\
5.74\end{array}$ & $\begin{array}{l}14.92 \\
16.1 \\
11.36\end{array}$ & $\begin{array}{l}24.5 \\
26.37 \\
11.61\end{array}$ & $\begin{array}{l}2.44 \\
2.87 \\
1.84\end{array}$ \\
\hline
\end{tabular}

${ }^{\mathrm{a}}$ Dust concentration given in $\mu \mathrm{g} \mathrm{m}^{-3}$, and column integrated dust mass given in $\mathrm{g} \mathrm{m}^{-2}$.

that empirical "tuning" of the $\alpha$ parameter is frequently required (see section 5 for further discussion).

[8] The DREAM model uses the dust emission scheme originally developed by Shao et al. [1993] in which the dust flux, $F$, is, again, a function of the third power of wind friction velocity.

$$
F=c \times \delta \times u_{*}^{3}\left[1-\left(u *_{t i} / u *\right)\right]
$$

Dust flux is scaled by dust productivity factor $\delta$ which takes into account effects of soil structure and particle size distribution, and a constant, $c$ (conceptually similar to the $\alpha$ parameter in equation (1)). Dust flux is then used to determine the surface dust concentration. However, unlike the other models, DREAM includes a viscous sublayer between the surface and the lowest model layer [Janjic, 1994], since there is a physical similarity between mass/ heat/momentum exchange over surfaces such as the ocean with that of mobilized dust particle over desert surfaces [Chamberlain, 1983; Segal, 1990]. This parameterizes the turbulent transfer of dust into the lowest model layer accounting for different turbulent regimes, using the simulated surface dust concentration as the lower boundary. More details on this scheme can be found in Nickovic et al. [2001] and Pérez et al. [2006b]. As a forecast model DREAM has been extensively "tuned" with respect to observations of AOT over North Africa by optimizing the constant $c$ in the dust flux equation (2).

[9] This saltation and sandblasting mechanism parameterized in equation (1) is commonly used in dust models. However, observations during BoDEx 2005 showed that in the diatomite sediments of the Bodélé depression the actual process of dust generation is more complex [Warren et al., 2007]. In the Bodélé saltation and sandblasting occur mostly where transport of sand sized quartz particles from the surrounding sand dunes is pronounced, largely at the northeastern end of the diatomite sediment where the dune density is highest. However, over most of the diatomite sediment of the Bodélé an unusual process of "autoabrasion" occurs; in which saltating diatomite aggregates themselves disintegrate into fine dust sized particles [Warren et al., 2007]. This dust generation mechanism has yet to be parameterized in dust models. Therefore, in this model intercomparison we evaluate the extent to which the Marticorena and Bergametti [1995] scheme (equation (1)) and the Shao et al. [1993] scheme of DREAM (equation (2)), under various model configurations, can represent these processes.

[10] Various model output fields at 3-hourly resolution were processed for comparative purposes over the period 10-12 March 2005 during a substantial dust event. The variables represent the driving winds (Table 1), the processes of dust emission (Table 2) and resulting dust burden (Tables 3 and 4) and transport (Table 5). In this study no consideration of deposition rates is made. The research teams involved were free to configure their model experiments as they chose. This condition was agreed for logistical reasons. Therefore, the model horizontal and vertical resolution, domain size, driving boundary conditions, land surface conditions, run duration, and dust physical and optical properties vary between the models, as summarized in Table A1 in Appendix A. Although the differences between model configurations mean the model outputs need to be carefully interpreted, the results provide an initial benchmark of model uncertainty. Future model intercomparison projects can then utilize a more tightly constrained model configuration. For display and analysis model output data were remapped to a common $0.2^{\circ}$ spatial resolution over the domain of $12^{\circ} \mathrm{E}-24^{\circ} \mathrm{E}, 12^{\circ} \mathrm{N}-24^{\circ} \mathrm{N}$ and a common vertical resolution of $100 \mathrm{~m}$ in the lowest $2 \mathrm{~km}$ of the atmosphere. All dust quantities except AOT were integrated over the size range of $0.1-10 \mu \mathrm{m}$ diameter to represent the component involved in long-range transport. Estimates of AOT were provided by the model teams and are based on the dust optical properties and size distributions specified in each model.

\subsection{Comparative Data}

[11] The focus of this intercomparison study is the large dust event of 10-12 March 2005. We have collated observations of local meteorology and estimates of dust burden, emission flux and aerosol optical thickness from various sources, for comparison with model output. Large-scale meteorological fields were obtained from National Centers for Environmental Prediction (NCEP) reanalysis for the

Table 4. Dust Model Results for Mean AOT Averaged Over 10-12 March 2005

\begin{tabular}{lccccc}
\hline \multicolumn{1}{c}{ Averaging Area } & RegCM3 & LM-MUSCAT & Meso-NH & RAMS-DPM & DREAM \\
\hline Chicha & 0.93 & 4.29 & 6.53 & 3.67 & 1.82 \\
Area $<250 \mathrm{~m}$ height & 0.85 & 4.71 & 6.47 & 3.95 & 1.74 \\
$14^{\circ} \mathrm{E}-21^{\circ} \mathrm{E}, 14^{\circ} \mathrm{N}-21^{\circ} \mathrm{N}$ & 0.58 & 2.1 & 4.23 & 1.38 \\
\hline
\end{tabular}


Table 5. Dust Model Results for Net Westward Dust Mass Flux Integrated Over $12.5^{\circ} \mathrm{N}-21^{\circ} \mathrm{N}$ and $10-12$ March $2005^{\mathrm{a}}$

\begin{tabular}{|c|c|c|c|c|c|}
\hline Quantity & RegCM3 & LM-MUSCAT & Meso-NH & RAMS-DPM & DREAM \\
\hline Flux at $16^{\circ} \mathrm{E} 10-12$ March 2005 & 0.44 & 4.59 & 4.89 & 12.8 & 0.79 \\
\hline Flux at $12.5^{\circ} \mathrm{E} 11-12$ March 2005 & 0.29 & 2.32 & 2.76 & N/A & 0.54 \\
\hline
\end{tabular}

${ }^{\mathrm{a}}$ Dust mass flux given in $\mathrm{Tg} \mathrm{d}^{-1}$.

study period and the ERA-40 reanalysis for the long-term mean. Satellite estimates of AOT were obtained from the "Deep Blue" algorithm of Hsu et al. [2004] applied to Seaviewing Wide Field-of-view Sensor (SeaWiFS) and MODerate resolution Imaging Spectroradiometer (MODIS) data $\left(0.1^{\circ}\right.$ resolution, daily at local noon) providing estimates even over highly reflective desert surfaces. SeaWiFS observed the study region on 10 and 12 March only, and there is some cloud contamination on 10 March. It should be acknowledged that Deep Blue estimates of AOT are subject to uncertainties, most notably those associated with assumptions about the aerosol size and shape and vertical distribution used in the generation of the look-up tables of satellite radiances associated with AOT and single scattering albedo. Estimates of AOT from the Multiangle Imaging SpectroRadiometer (MISR) system have very limited coverage over the Bodélé during the period of interest and are only used for calculation of dust mass transport downwind where an overpass occurred. In situ data were obtained from the Bodélé Dust Experiment (BoDEx 2005). Observations of $2 \mathrm{~m}$ height winds (converted here to $10 \mathrm{~m}$ height using a logarithmic wind profile defined with an appropriate roughness length value for desert surfaces) and AOT measured using a microtops Sun photometer were made at "Chicha" $\left(16.9^{\circ} \mathrm{N}, 18.5^{\circ} \mathrm{E}\right)$. Observations of AOT were necessarily sporadic owing to very high dust emissions rendering observation problematic.

[12] Model output and observations are compared at three spatial scales: (1) point quantities at Chicha, (2) quantities averaged over an area which approximates the area of exposed diatomite sediment, defined by the grid cells lower than the $250 \mathrm{~m}$ surface height contour in the RegCM3 model domain, and (3) quantities averaged over the domain $14^{\circ} \mathrm{N}-21^{\circ} \mathrm{N}, 14^{\circ} \mathrm{E}-21^{\circ} \mathrm{E}$, which covers the area from the northern point of lake Chad in the southwest to the TibestiEnnedi gap in the northeast, encompassing the dust plumes in their entirety. These domains are approximately indicated on Figure 1a.

\section{Overview of the Climate of the Bodélé Depression}

[13] In winter, North Africa including the Chadian sector is dominated by the low-level northeasterly Harmattan winds [Hamilton and Archibald, 1945; Hastenrath, 1988], which occur in the lowest $100 \mathrm{hPa}$ of the atmosphere. These winds are driven by north-south pressure gradient between the mean high-pressure ridge centered over Libya (the Libyan High) and the equatorial trough (Figure 2a). The Bodélé LLJ is embedded in this mean northeasterly Harmattan wind and is oriented NE-SW with a mean maximum of $\sim 12 \mathrm{~m} \mathrm{~s}^{-1}$ (at the $925-\mathrm{hPa}$ level in reanalysis) centered near $17^{\circ} \mathrm{N}, 19^{\circ} \mathrm{E}$ in the ERA-40 reanalysis data (Figure 2a). Mean wind speeds at $925 \mathrm{hPa}$ in excess of $11 \mathrm{~m}$ $\mathrm{s}^{-1}$ extend over a large region from northern Chad to Lake
Chad, a distance of some $1200 \mathrm{~km}$. The high wind speeds to the northwest of the Tibesti mountains (centered near $22^{\circ} \mathrm{N}$, $14^{\circ} \mathrm{E}$ ) indicate a split in the Harmattan wind associated with the presence of the mountains.

[14] The LLJ exhibits a pronounced diurnal cycle with a nighttime (daytime) maximum (minimum) consistent with the inertial oscillation mechanism [Blackadar, 1957; Washington et al., 2006; Todd et al., 2008]. During the day, surface heating leads to a well mixed deep boundary layer that exerts a frictional deceleration of the LLJ. After sunset, radiative cooling of the surface leads to a nearsurface temperature inversion and decoupling of the surface and low-level winds. This initiates an inertial oscillation in which the LLJ accelerates through the night, until turbulent mixing starts again the following day. This process leads to an out-of-phase relationship of the diurnal cycle of the LLJ with respect to that of surface winds. At the surface, maximum wind speeds are observed during midmorning when turbulence mixes the momentum of the nocturnal LLJ down to the surface. At night, decoupling of the surface and low levels leads to minimum wind speeds at the surface and LLJ maximum [Washington et al., 2006; Todd et al., 2008]. This pattern is typical of many regions in the tropics that experience a nocturnal LLJ phenomenon [e.g., May, 1995; Parker et al., 2005; Sultan et al., 2007; Knippertz, 2008]. Accordingly, dust production is 'locked' to the diurnal cycle of surface winds and tends to peak during the early mid morning, and weaken during the afternoon [Washington et al., 2006; Todd et al., 2007; K. Schepanski et al., Meteorological processes forcing Saharan dust emission inferred from MSG-SEVIRI observations of subdaily dust source activation, submitted to Journal of Geophysical Research, 2008]. This results in discrete daily pulses of dust that are then transported out of the region within the LLJ [Koren and Kaufman, 2004; Todd et al., 2007].

[15] Although the nocturnal LLJ is a widespread phenomenon in the region, it is strongest and most pronounced over the Bodélé depression as a result of the local orographic configuration. The northeasterly flow is channeled through the Tibesti-Ennedi gap (Figure 2a) and the combination of a gap wind and downslope wind-forcing acts to accelerate the LLJ by up to $50 \%$ [Todd et al., 2008]. Dust events occur when surface winds exceed the threshold velocity for dust emission (about $10 \mathrm{~m} \mathrm{~s}^{-1}$ at $2 \mathrm{~m}$ height [Todd et al., 2007]). Outside of summer, variability in surface winds is associated with day-to-day synoptic-scale variability in the strength of the north-south pressure gradient across the region, most notably controlled by ridging of the Libyan High [Washington and Todd, 2005]. Thus, the temporal characteristics of dust emission from the Bodélé during winter results from the interaction of the basic state of the atmosphere over North Africa, local/regional topography, synoptic variability and the coupled diurnal cycle of the LLJ and surface winds. 

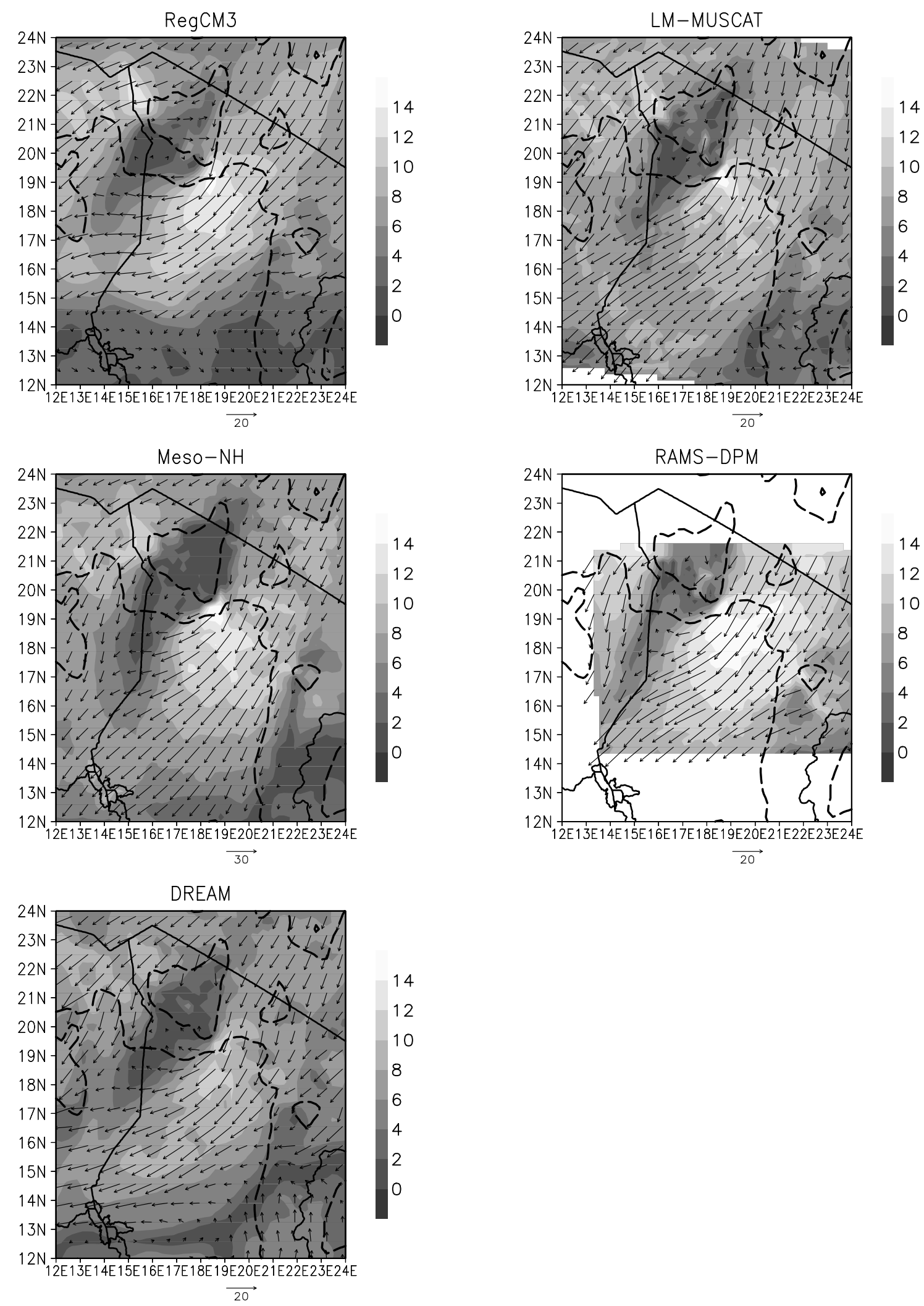

Figure 3. Model simulated $925 \mathrm{hPa}$ winds ( $\mathrm{m} \mathrm{s}^{-1}$, vectors) and $10-\mathrm{m}$ scalar wind speed $\left(\mathrm{m} \mathrm{s}^{-1}\right.$, shading) at 0900 UTC on 10 March 2005. The 500-m and 1000-m surface elevation (dashed line) contours are shown. 


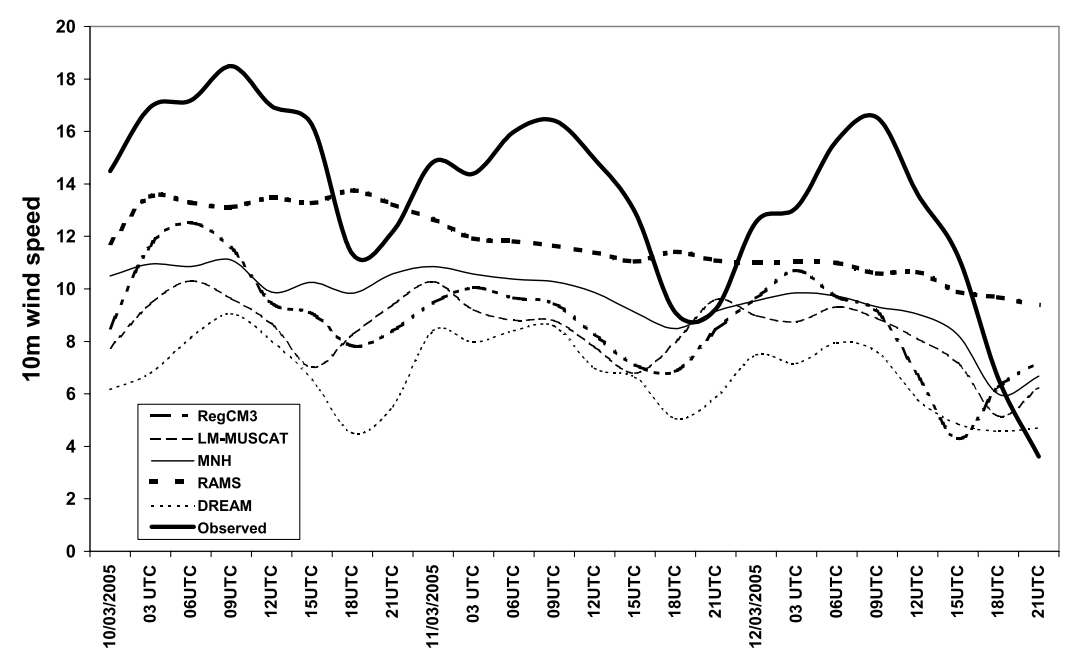

Figure 4. Time series of in situ observed and model simulated $10 \mathrm{~m}$ height wind speed at Chicha $\left(\mathrm{m} \mathrm{s}^{-1}\right)$.

[16] The large dust event from 10 to 12 March 2005 occurred when a blocking anticyclone over the northeastern Atlantic suddenly migrated eastward and extended a pronounced ridge across North Africa, drawing an anomalously strong north-northeasterly flow across the Bodélé region (Figure $2 \mathrm{~b}$ ). The structure and duration of this circulation pattern is quite typical condition for wintertime Bodélé dust events [Washington and Todd, 2005], resulting in pronounced dust emission over 3 days. Typically, the diurnal cycle of winds resulted in emission occurring in pulses that peaked after sunrise and ceased during the late afternoon/ evening in each day.

\section{Results and Discussion}

\subsection{Simulation of Regional Winds}

[17] The models under study here all provide similar representation of the spatial structure of the LLJ and $10 \mathrm{~m}$ height winds (Figure 3). Key features include a split jet north and south of the Tibesti Mountains with peak wind speeds located immediately south of Tibesti, both in the 3-day time mean and instantaneous fields (Figure 3). All models, except RAMS-DPM, also simulate well the day-today variability at the location of Chicha (Figures 4 and 5). All models have a nocturnal LLJ maximum peaking below $1000 \mathrm{~m}$ elevation, but this is rather weakly defined in RAMS-DPM. The models LM-MUSCAT, RegCM3 and DREAM all simulate a nocturnal LLJ of similar structure and magnitude, with peak wind speeds of $20-24 \mathrm{~m} \mathrm{~s}^{-1}$ on 10 March 2005, likely to be lower than the real LLJ wind speeds [Todd et al., 2008]. In addition, all models underestimate mean (in situ) $10 \mathrm{~m}$ height winds by $13-50 \%$ (Table 1 and Figure 4). RAMS-DPM simulates the highest mean wind speeds, but with peak wind speeds $\sim 30 \%$ lower than in situ observations. It is interesting to note that in the LM-MUSCAT model when the dust-radiative feedback is not activated surface wind speed underestimation is reduced (I. Tegen, personal communication, 2008). All models except RAMS-DPM have pronounced diurnal cycle in surface winds and LLJ but have smaller amplitude than observations (Figures 4 and 5). However, only the DREAM model captures the diurnal phase of wind speed maxima at
0900 UTC consistent with observations. All other models tend to produce the peak rather too early by $\sim 3 \mathrm{~h}$ typically. In these models the diurnal cycle of near-surface wind speed is in phase with LLJ jet core such that downward mixing of nocturnal LLJ may not be well simulated. There does not appear to be a relationship between model horizontal or vertical resolution and the accuracy of near-surface wind speed estimates.

[18] Todd et al. [2008] undertook a sensitivity study using the MM5 mesoscale model for near-surface and boundary layer winds over the BoDEx period. They note that there is a factor of $\sim 2$ variation in mean and peak wind speeds over the BoDEx period using MM5 under various configurations. Simulated winds are most sensitive to the model Planetary Boundary Layer (PBL) scheme and vertical resolution in the lowest $200 \mathrm{~m}$. Ten-meter wind speeds from the models in the present study lie within the range simulated using the MM5 model of Todd et al. [2008]. Under an optimized configuration (Eta PBL scheme, 15 vertical levels in lowest $1000 \mathrm{~m}$ with lowest level at $2 \mathrm{~m}$, roughness length $=0.001 \mathrm{~m}$ ) the MM5 estimated LLJ and surface wind speeds and phase are close to observed quantities. This suggests that improved representation of the surface and low-level winds responsible for emission and transport of dust in these models would be possible with careful model configuration. Indeed, Laurent et al. [2008a] report that a more recent version of RAMS (v6.0) that includes an improved soil scheme provides a more realistic simulation of the diurnal cycle of surface winds than the version used in this study and by Bouet et al. [2007].

\subsection{Simulation of Dust Emission and Transport \\ 4.2.1. Dust Emission}

[19] Emission estimates are available for all models except Meso-NH. Estimates of dust emission from DREAM are not directly comparable to those of the other models, owing to the use of a viscous sublayer close to the surface (see section 2.1), and are not presented here. The spatial structure in emission (Figure 6) is broadly similar in RAMS-DPM, LM-MUSCAT and RegCM3 with emission restricted to areas of low elevation close the Bodélé depression. RegCM3 produces localized emission sources which 

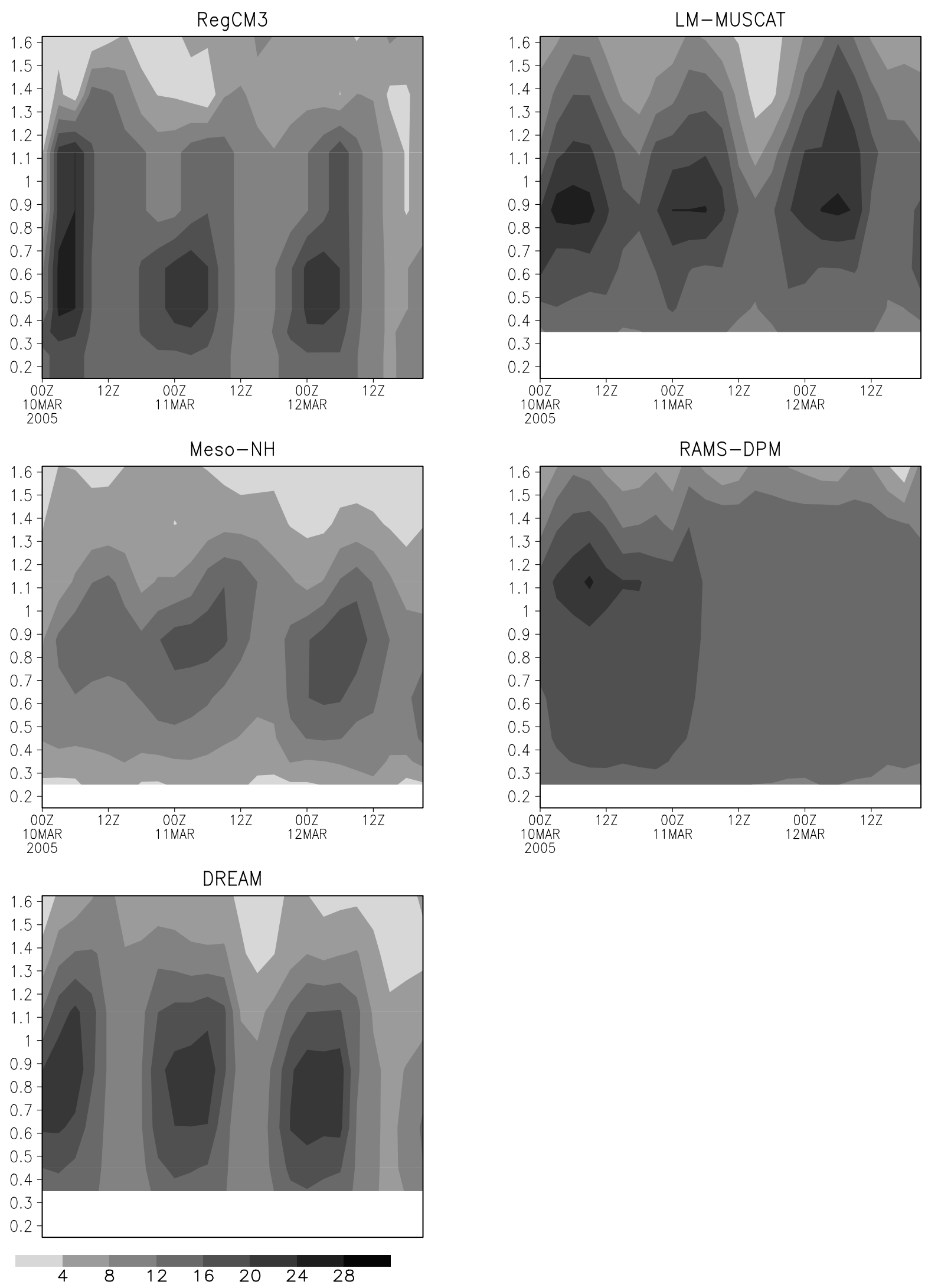

Figure 5. Time series of model simulated vertical profile of wind speed at Chicha $\left(\mathrm{m} \mathrm{s}^{-1}\right)$. The $y$ axis is height above the surface in kilometers. Note that for Meso-NH the location is $16^{\circ} \mathrm{E}, 17^{\circ} \mathrm{N}$. 

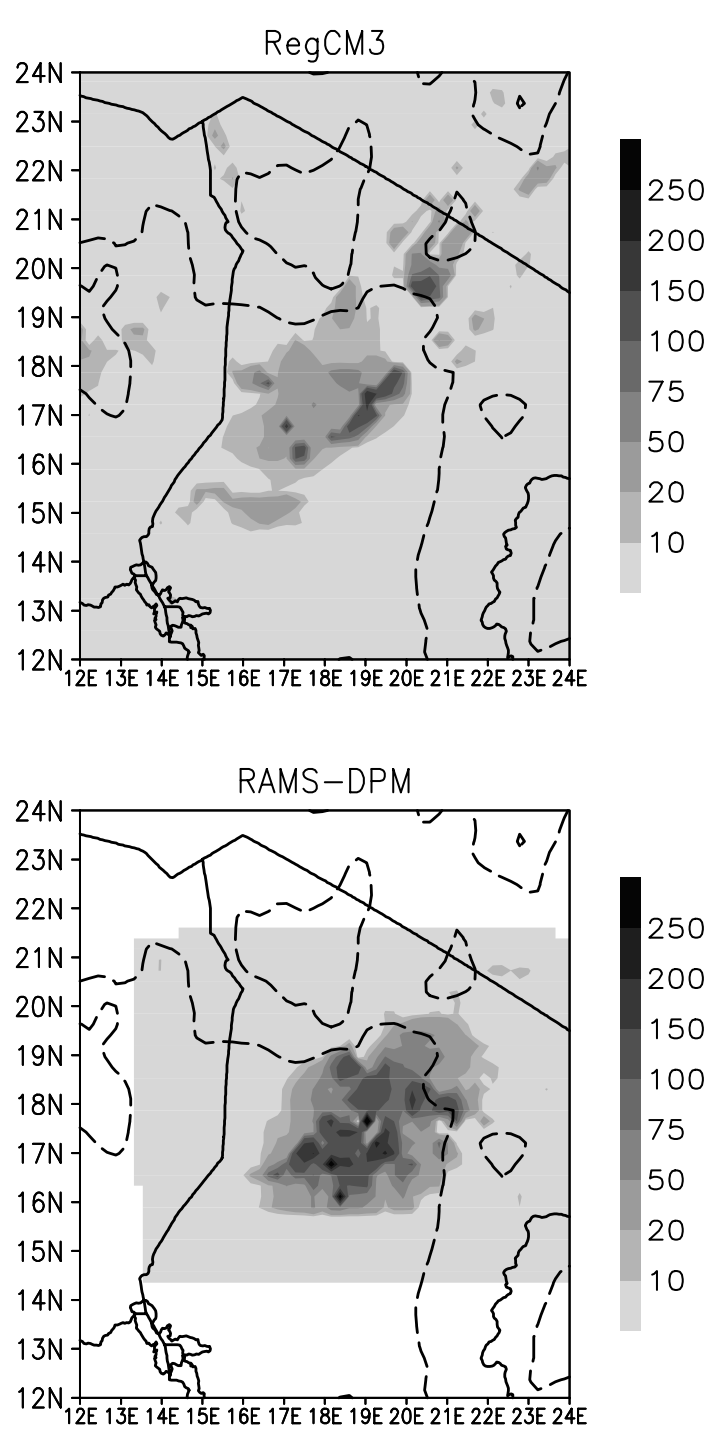

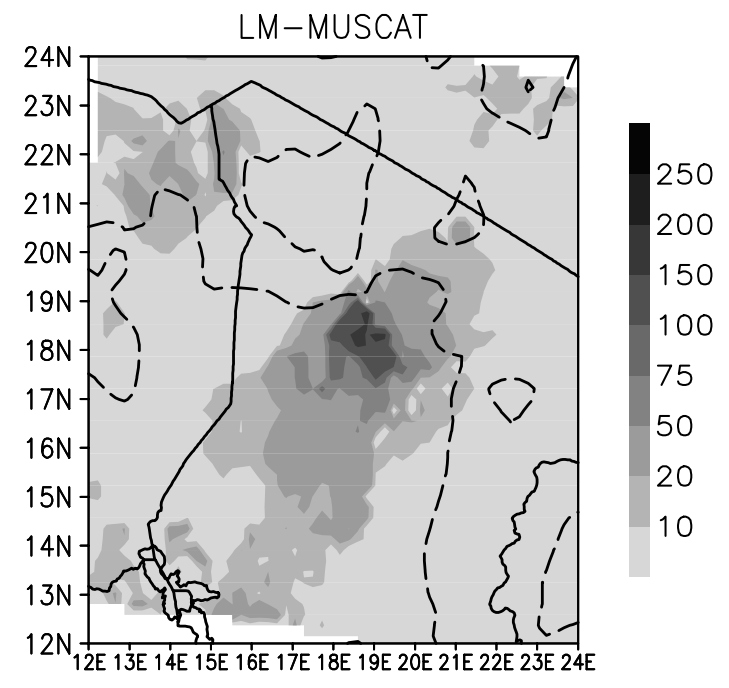

Figure 6. Model simulated mean rate of surface dust emission 10-12 March $2005\left(\mathrm{~g} \mathrm{~m}^{-2} \mathrm{~s}^{-1}\right)$. The $500-\mathrm{m}$ and 1000-m surface elevation (dashed line) contours are shown.

represent well the areal extent of the localized outcrops of diatomite sediment identified as the dust source regions in satellite observations (see below), although not in precisely the same location. In the model these locations correspond to the areas where the soil texture (derived from the FAO/ USDA (Food and Agriculture Organization of the United Nations/United States Department of Agriculture) map) is $100 \%$ sand, rather than a representation of diatomite, thus activating dust emission by saltating sand particles via the Marticorena and Bergametti [1995] emission parameterization. In LM-MUSCAT emission is highest from regions north of $17^{\circ}$. In this model preferential dust sources are parameterized to ensure that areas of high dust productivity are collocated with enclosed topographic depressions including the Bodélé depression [Tegen et al., 2006].

[20] At the location of Chicha, dust emission closely matches the diurnal cycle of near-surface winds, such that the models (except RAMS-DPM) do simulate a diurnal "pulsing" of emission (not shown). Mean emission from the three models available (Table 2 ) show an approximately two to threefold range in mean and peak dust emission at the location of Chicha and averaged over the wider domains. Estimates of total emission from the exposed diatomite area within the Bodélé depression were calculated from the product of the mean emission rate over the area less than $250 \mathrm{~m}$ elevation (which approximates the diatomite location) and the area of diatomite $\left(10,800 \mathrm{~km}^{2}\right.$, derived from MODIS surface reflectance data, Figure 1a). Over the 3 days 10-12 March 2005, estimates range between $1.4 \mathrm{Tg}$ for RegCM3 to $3.6 \mathrm{Tg}$ for RAMS-DPM (Table 2). Todd et al. [2007] estimated the total dust flux from the Bodélé during the 3-day dust event of 1012 March 2005 using a simple relationship of surface wind speed and vertically integrated dust flux relationship derived empirically from observations at Chicha, then scaled to the entire area of diatomite sediment. Their estimate was $3.54 \mathrm{Tg}$, which falls at the upper end of the range of model estimates. It should be noted, however, that the models do not all show peak emission collocated with the region $<250 \mathrm{~m}$ height (Figure 6). The equivalent values for the entire domain $\left(12^{\circ} \mathrm{E}-21^{\circ} \mathrm{E}, 12^{\circ} \mathrm{N}-21^{\circ} \mathrm{N}\right)$ range from 21.1 Tg for RegCM3 to $42.5 \mathrm{Tg}$ for RAMS-DPM (Table 2). 

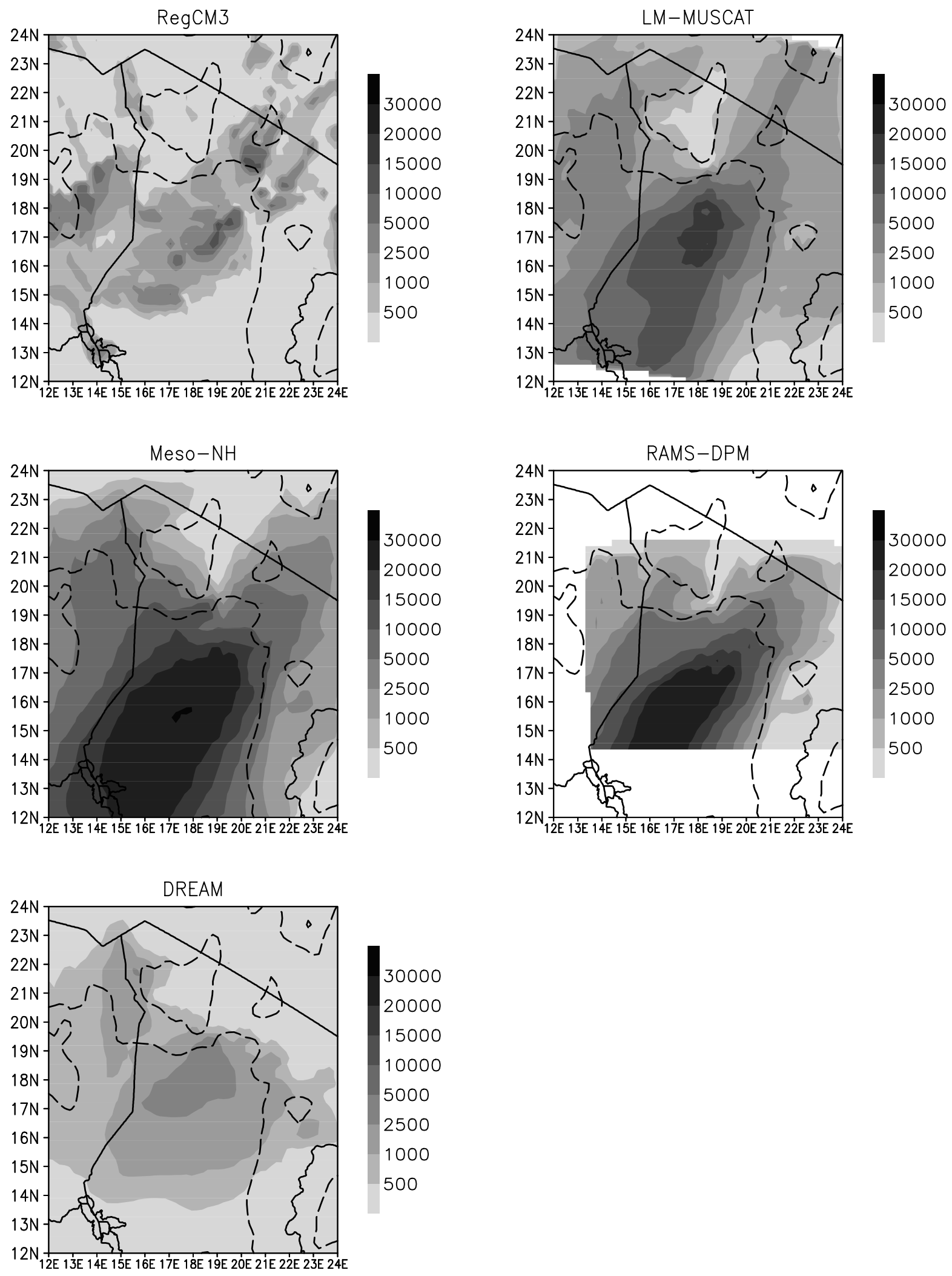

Figure 7. Model simulated mean dust concentration in model lowest layer 10-12 March $2005\left(\mu \mathrm{g} \mathrm{m}^{-3}\right)$. The 500-m and 1000-m surface elevation (dashed line) contours are shown. 


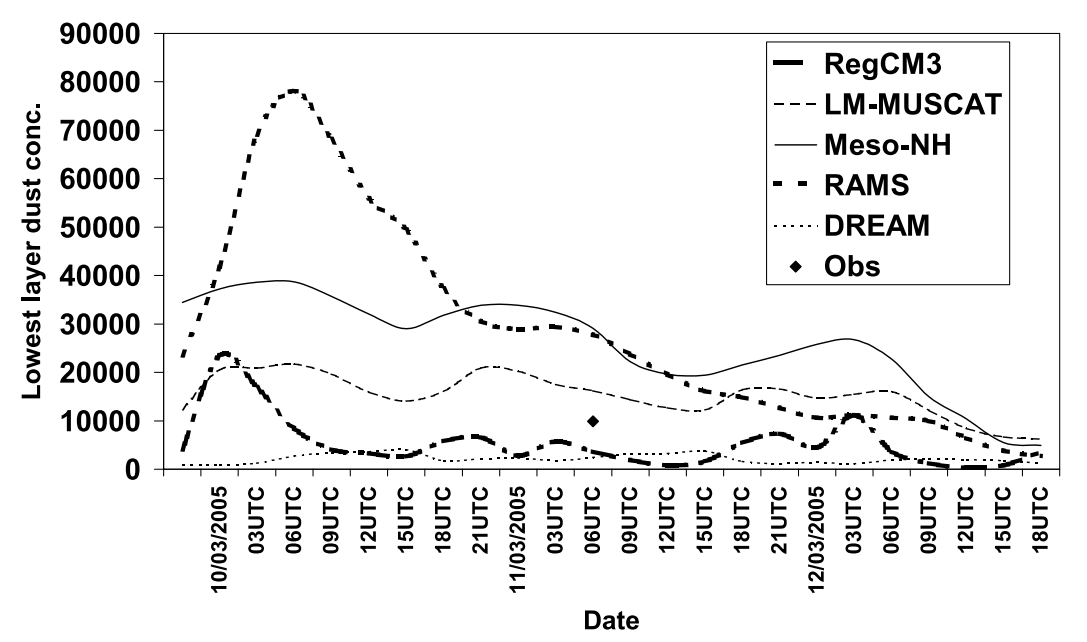

Figure 8. Time series of model simulated dust concentration in model lowest layer $\left(\mu \mathrm{g} \mathrm{m}^{-3}\right)$ at the location of Chicha.

\subsubsection{Dust Concentration}

[21] Mean dust concentration $(0.1-10 \mu \mathrm{m}$ diameter $)$ in the lowest model layer show a wide range between the models (Figure 7). Over the study domain as a whole, Meso-NH has the highest mean value, up to $30,000 \mu \mathrm{g} \mathrm{m}^{-3}$ and DREAM the lowest, about one tenth of that of MesoNH. RAMS-DPM has similarly high peak values but over a more restricted dust plume area. At Chicha, model mean dust concentration values range over about 1 order of magnitude from 2100 (DREAM) to $26,000 \mu \mathrm{g} \mathrm{m}^{-3}$ (Meso-NH) (Table 3). Similar values are estimated over the region with elevation $<250 \mathrm{~m}$ with RAMS and Meso$\mathrm{NH}$ producing dust concentration of about 1 order of magnitude greater than DREAM. In most models dust concentration at Chicha shows the diurnal pulsing and peaks at 0900 UTC on 10 March when RAMS simulates the highest value of $78,000 \mu \mathrm{gm}^{-3}$ (Figure 8). In situ observations at Chicha are limited but a maximum value of $9900 \mu \mathrm{gm}^{-3}$ at $2 \mathrm{~m}$ height was observed at $1000 \mathrm{UTC}$ on 11 March (Figure 8). Observed dust concentrations therefore lie toward the lower end of the range simulated in the dust models. Caution must be exercised in comparing the models owing to the varying heights of the lowest model layers. As noted above dust emission fields were not available from Meso-NH and DREAM. However, as Meso-NH produces the highest dust concentration of all models it is likely to have the highest emission. This may be related to the soil data used whereby the soil texture is dominated by sand across the entire domain $14^{\circ} \mathrm{N}-17^{\circ} \mathrm{N}$ leading to a high horizontal saltation flux and subsequent emission.

\subsubsection{Aerosol Optical Thickness}

[22] Dust emitted from the surface is transported in the low-level northeasterly winds in all models. As a result, all models simulate NE-SW oriented dust plumes (centered below $1000 \mathrm{~m}$ elevation, not shown), which have the fundamental characteristics of the observed data (Figures 7, 9, 10, and 11). Thus, despite small-scale differences in the location of dust source regions the coherent northeasterly LLJ results in dust plumes that are generally good representations of reality. Nevertheless, most models produce a tongue of high atmospheric dust loadings extending to the north of the main NE-SW oriented plume, centered close to the ChadNiger border north of about $17^{\circ} \mathrm{N}$. Satellite estimates of AOT do not show elevated AOT values there (Figures 10 and 11). The time evolution of the dust plumes shows rapid transport to the southwest in all cases, with the dust transported in distinct diurnal "packets" in most cases. The speed of propagation differs however and the time taken for dust transport to $14^{\circ} \mathrm{E}$ (the longitude of Lake Chad) varies between about $9 \mathrm{~h}$ for Meso-NH and about $15 \mathrm{~h}$ for DREAM.

[23] The time-mean column dust mass $(0.1-10 \mu \mathrm{m}$ diameter) at Chicha varies from $1.91 \mathrm{~g}^{-2}$ in RegCM3 to $24.5 \mathrm{~g}^{-2}$ in RAMS-DPM (Table 3). At Chicha the time distribution of dust mass is similar in most models with a peak near 1200 UTC on 10 March and subsequent decline (Figure 12). Estimates based on in situ data from Todd et al. [2007] fall toward the lower end of the model range closest to the estimates by the RegCM3 and DREAM models. There is about a 15-fold difference in mean column dust mass between RAMS-DPM and RegCM3 averaged over the whole domain (Table 3).

[24] While there is generally close agreement between the models in terms of the spatial structure of AOT there is an approximately sevenfold range in simulated AOT at all spatial scales (Figures 10 and 11 and Table 4). Meso-NH estimates the highest AOT and RegCM3 the lowest. Satellite estimates of AOT from the "Deep Blue" algorithm applied to SeaWiFS and AI from OMI data indicate the distinct dust NE-SW oriented plumes. The spatial structure is particularly well represented by RegCM3 and RAMSDPM, with Meso-NH and LM-MUSCAT overestimating the areal extent of the plume and DREAM locating the plume rather too far north, a consequence of the source areas and plume propagation speed. We should be aware of potential errors in the Deep Blue aerosol product but the Aerosol Index product [Herman et al., 1997] from the Ozone Monitoring Instrument (OMI, not shown) presents a very similar spatial structure to the Deep Blue AOT.

[25] A quantitative comparison of AOT is problematic as the "Deep Blue" algorithm saturates at a maximum AOT of 

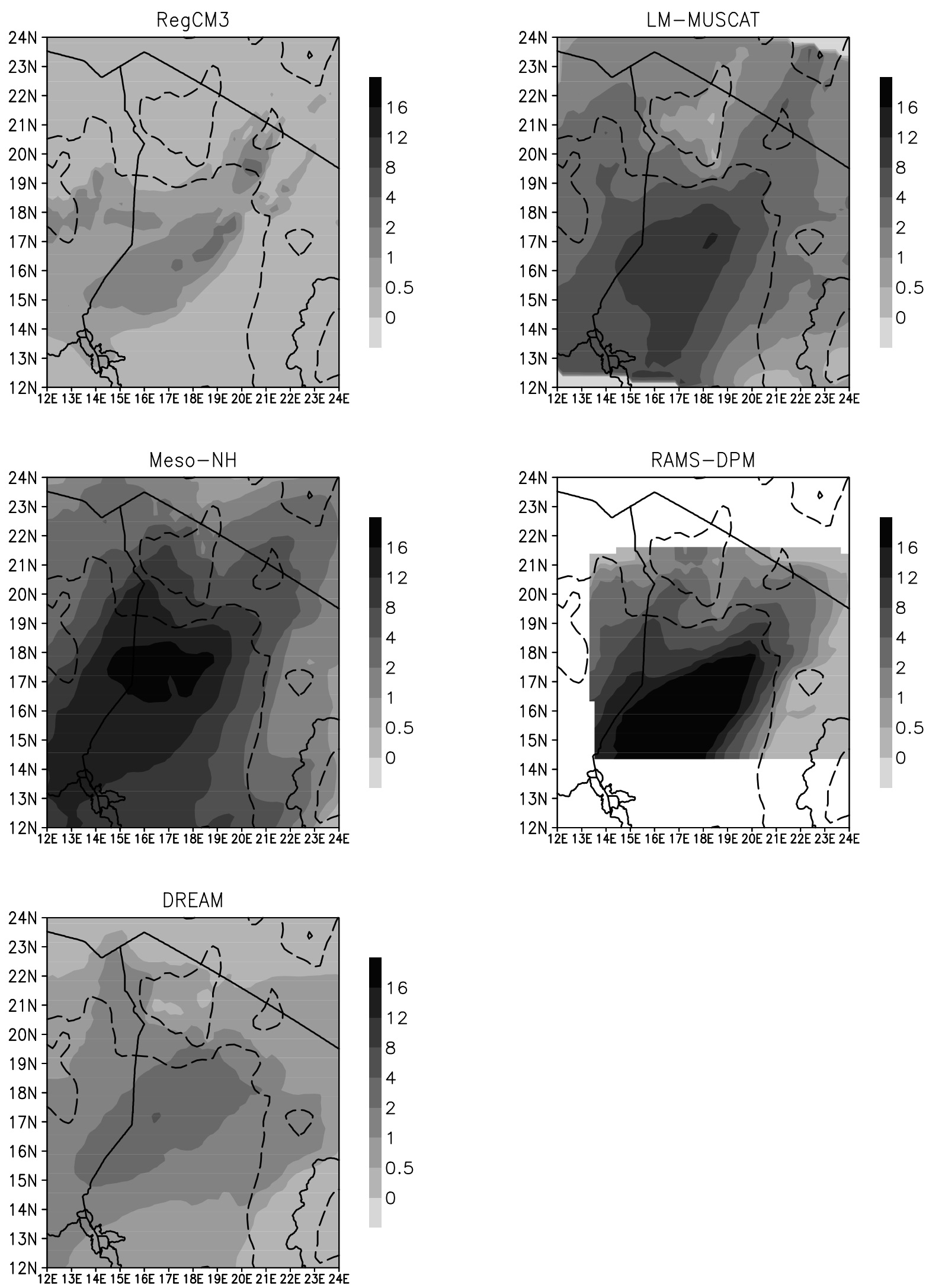

Figure 9. Model simulated mean vertically integrated dust mass $10-12$ March $2005\left(\mathrm{~g} \mathrm{~m}^{-2}\right)$. The $500-\mathrm{m}$ and 1000-m surface elevation (dashed line) contours are shown. 

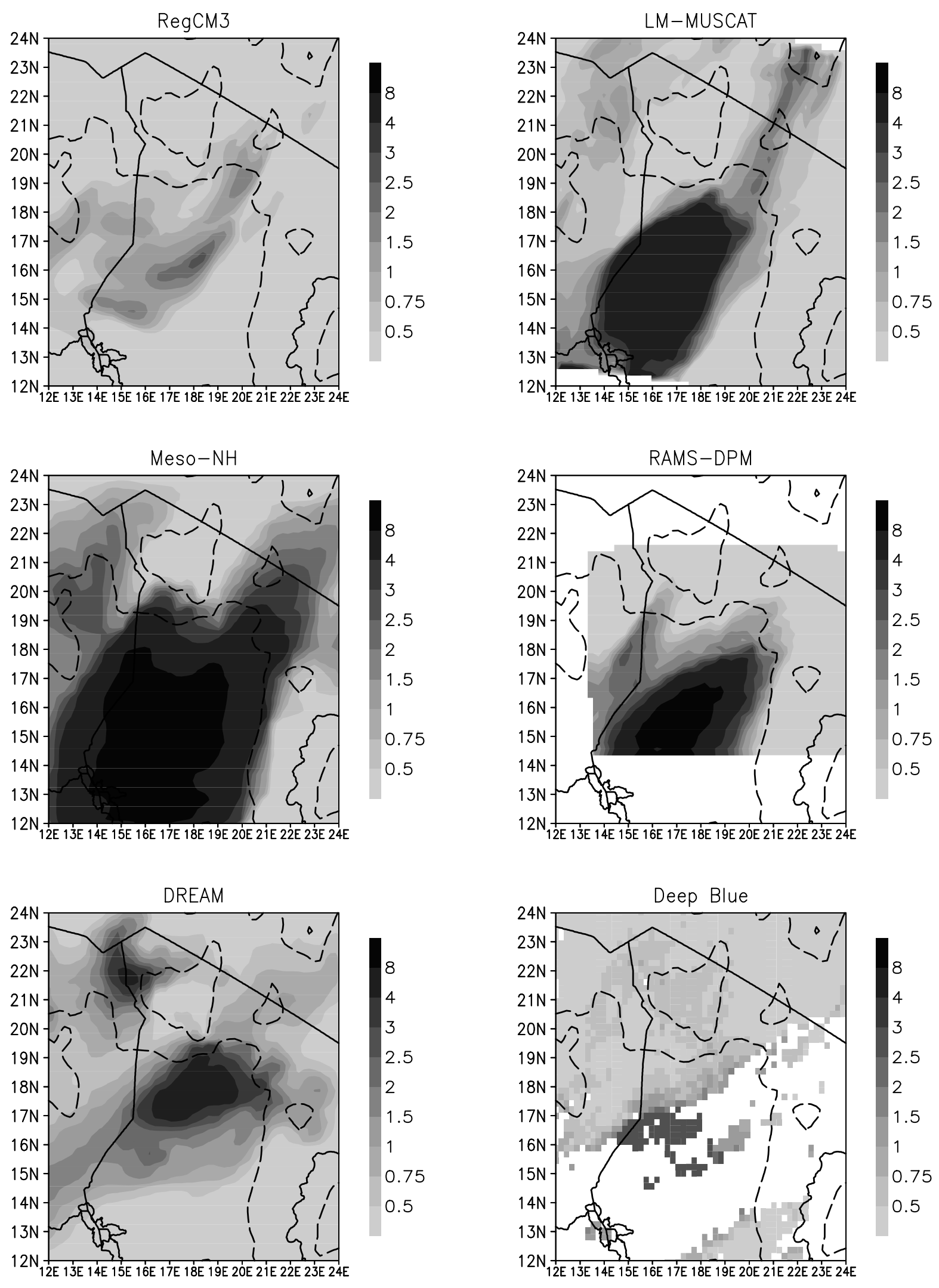

Figure 10. AOT estimated by models and "Deep Blue" satellite algorithm on 1200 UTC 10 March 2005. The 500-m and 1000-m surface elevation (dashed line) contours are shown. Note cloud contamination (white color) over dust plume in Deep Blue product. 

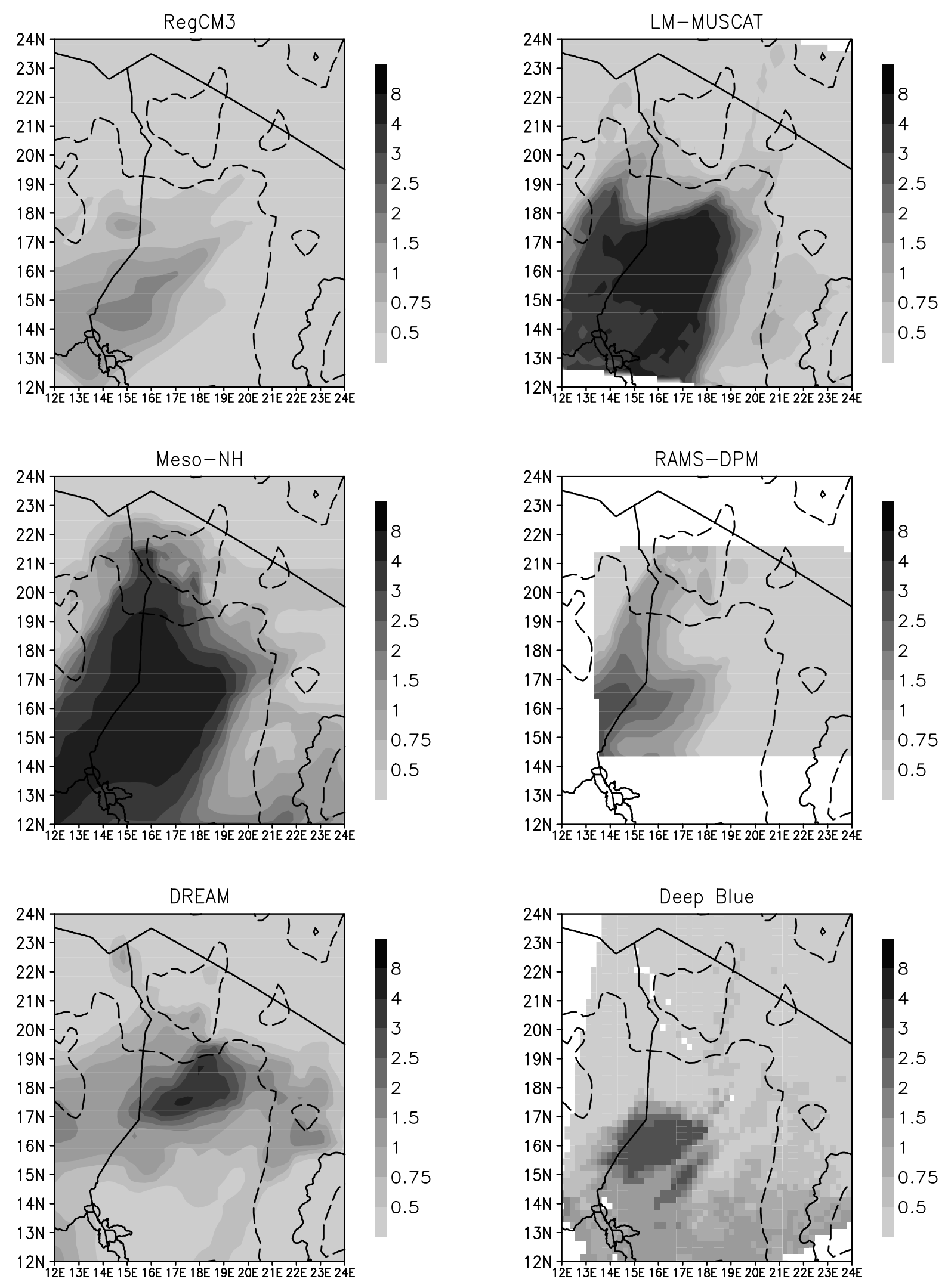

Figure 11. As in Figure 10 except for 1200 UTC on 12 March 2005. 


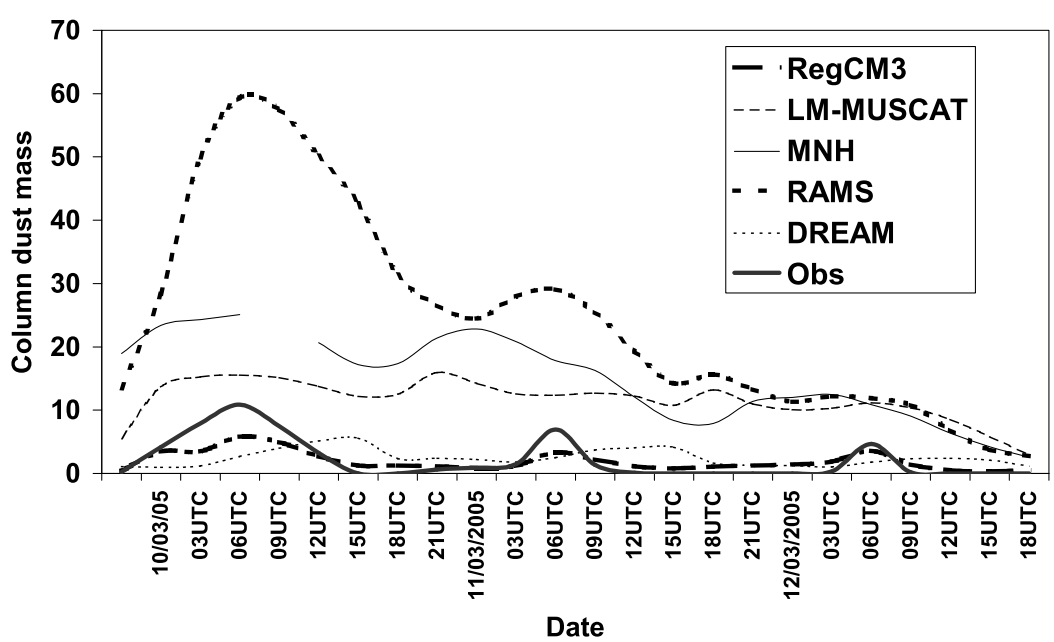

Figure 12. Time series of model simulated vertically integrated dust mass $\left(\mathrm{g} \mathrm{m}^{-2}\right)$ at the location of Chicha.

3.0. At Chicha limited observations of AOT were made during the afternoons of 11 and 12 March. On both days the decline in wind speeds after midday was such that transport exceeded local emission (which ceased in early afternoon) and AOT declined rapidly (Figure 13). All models except DREAM simulate this decline but the LM-MUSCAT and Meso-NH models overestimate AOT by about a factor of 2 while RegCM3 AOT is about $50 \%$ of observed. DREAM and RAMS-DPM provide a close agreement with observed AOT at Chicha during 11-12 March. Overall, the combined in situ and satellite observations indicate overestimation of AOT by Meso-NH and LM-MUSCAT and underestimation by RegCM3. Some of the overestimation by Meso-NH may result from use of a suboptimal $\alpha$ parameter derived from model "tuning" experiments conducted at lower resolution. Application of an updated $\alpha$ parameter would result in AOT estimates about one third lower (P. Tulet, personal communication, 2008). It is interesting to note that the ratio of model minimum to model maximum mean column dust mass (Table 3) is about twice that for AOT (Table 4) reflecting differences in the size distribution and the optical properties of the dust aerosols in the models. AOT calcu- lations in the models are based on the full size range of the dust particles.

\subsubsection{Long-Range Dust Transport}

[26] Previous studies, notably that of Koren et al. [2006], have clearly indicated substantial long-range transport of dust from the Bodélé. The impact of this on climate and remote ecosystems will depend on the mass flux from the region. Here, we derive the mass flux of dust from the region estimated by each model from the product of the wind speed and dust concentration in each model layer, summed over the atmospheric column. Dust transport is dominated by a westward flux in the Harmattan northeasterly flow such that in the vertical integration calculation at levels where the zonal wind component is eastward the dust flux is considered to be negative. The net flux is summed over the latitude range $12.5^{\circ} \mathrm{N}-21^{\circ} \mathrm{N}$. Therefore, the result represents the net westward export of dust mass from the entire region toward West Africa and the Gulf of Guinea. Estimates of westward dust flux over the 3 -day period leaving Chad at $16^{\circ} \mathrm{E}$ range widely from $0.44 \mathrm{Tg} \mathrm{d}^{-1}$ from RegCM3 to $12.8 \mathrm{Tg} \mathrm{d}^{-1}$ from RAMS-DPM (Table 5).

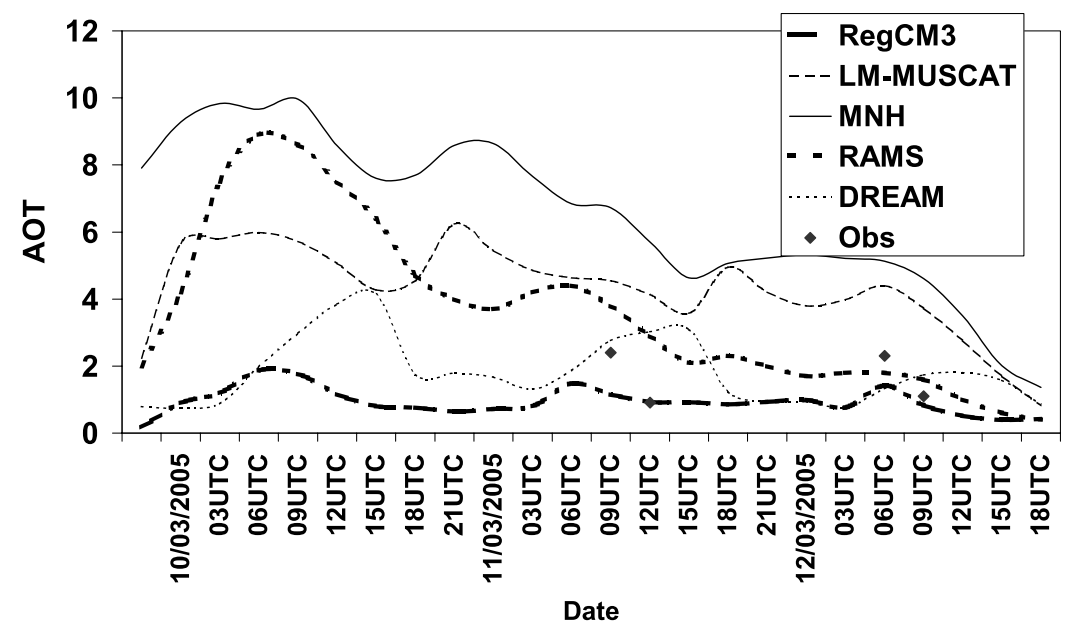

Figure 13. Time series of model simulated and observed AOT at the location of Chicha. 
[27] Koren et al. [2006] estimate the long-range dust flux from the Bodélé by identifying dust plumes from MODIS satellite imagery and determining their average dimensions after 1 day when the plume lies to the west of Lake Chad. The dust mass within the plume was then derived from the product of plume area and column integrated dust mass, estimated from the satellite MISR-derived AOT. The average plume mass over the period October 2003 to October 2004 was estimated to be $0.77 \mathrm{Tg} \mathrm{d}^{-1}$. The same method is applied to the BoDEx dust event except that we consider a greater range of uncertainty in the estimates associated with (1) satellite AOT, by considering contrasting estimates derived from MISR and the "Deep Blue" algorithm applied to MODIS data, and (2) the conversion of AOT to dust mass, by using the contrasting values of Koren et al. [2006] $\left(2.7 \mathrm{~g}^{-3}\right)$ and Todd et al. [2007] $\left(1.9 \mathrm{~g}^{-3}\right.$, updated using Sun photometer observations at the AERONET (AErosol RObotic NETwork, Holben et al. [1998]) station at Maine Soroa $\left(12.02^{\circ} \mathrm{E}, 13.22^{\circ} \mathrm{N}\right)$, downwind from the Bodélé). The resulting estimated range of the dust mass flux for the emission events of 10-11 March 2005 is $0.9-2.9 \mathrm{Tg} \mathrm{d}^{-1}$, not accounting for uncertainty in the estimates of dust area. Assuming these "1-day-old" plumes identified from MODIS are centered on $13^{\circ} \mathrm{E}$ then the equivalent estimates for the models are $0.299,2.31,2.76$ and $0.54 \mathrm{Tg} \mathrm{d}^{-1}$ from the RegCM3, LM-MUSCAT, Meso-NH and DREAM models, respectively (Table 5), and we might expect higher values from RAMS-DPM had data been available at $13^{\circ} \mathrm{E}$. As such, the "observational" estimates using an updated method of Koren et al. [2006] lie within the model range.

\section{Discussion and Conclusions}

[28] A dust model intercomparison has been undertaken for a 3-day dust event over the Bodélé depression, the world's greatest single dust source region. The meteorology during the event was typical of wintertime dust events. The results here are not strictly intended to determine which models are "better" than others, and no single model performs better than the others in all aspects. Results show that near-surface wind speeds are underestimated by up to $50 \%$ and the out-of-phase relationship of the diurnal cycles of the LLJ and surface winds is not well resolved. The pronounced diurnal cycle in surface and lower level winds is present in most models and results in pulsed dust emission as in observations, but peak winds exhibit slight phase shift relative to observations in all but one model. In a comparable study of dust models over Asia, Uno et al. [2006] noted that for most locations wind speed observations lie within the range of model results. Underestimation of winds over the Bodélé may result from poor representation of surface and boundary layer conditions and processes highlighting the need for improved configuration of Regional Climate Models [Todd et al., 2008]. Given that in most dust schemes the dust flux is proportional to the third power of friction velocity then small errors in wind speeds can result in large dust flux uncertainties. In this study, generally, the models with highest wind speeds (RAMS and Meso-NH) do tend to produce the highest dust fluxes. However, the substantial differences in dust fluxes between models with similar wind magnitudes (e.g., Meso$\mathrm{NH}$, LM-MUSCAT and RegCM3) serve to highlight the importance of surface factors such as soil texture, soil size distribution and surface roughness in determining emission, as well as the calibration of the $\alpha$ factor in the emission equation (equation (1)).

[29] Models generally show good representation of Bodélé dust plumes over the period 10-12 March 2005 and the temporal variability. All have emission in the wider Bodélé region. At local scales, however, the sources of dust emission show variability between models and RAMSDPM and LM-MUSCAT show emission that is rather too spatially widespread, relative to observations. RegCM3 produces more localized emission from regions where, coincidentally, the soil texture map indicates pure sand soils. In reality, however, within the Bodélé depression the diatomite sediment has a range of size distributions and the soil data sets in the models do not represent this feature well. Moreover, the sandblasting emission scheme of the models is only partially applicable to the diatomite sediment. As such, the model representations of dust plumes in the region are rather crude representations of the complexity of actual emission process in the diatomite sediment of the Bodélé. It may be that the models based on the Marticorena and Bergametti [1995] scheme simulate reasonable dust emission from the Bodélé for the wrong reasons, i.e., because the soil maps erroneously indicate sandy soils. Nevertheless, for the purposes of simulating long-range transport and climate impact the models may be acceptable.

[30] The range of model estimates of quantities (for which we have estimates from all models, specifically surface dust concentration, vertically integrated dust mass and AOT) is approximately 1 order of magnitude. In terms of the total dust mass exported from the Bodélé depression the model estimates range over a factor of about 30 . It is reassuring, however, to note that observational estimates of the equivalent quantities from a range of sources do lie within the model range. It should be noted that the model estimates presented here do refer to a common dust particle size range $(0.1-10 \mu \mathrm{m}$ diameter) such that these differences between the models do not result from certain models having a wider or smaller range of particle sizes.

[31] The degree of model uncertainty reported here is actually very similar to the range of mean emission and typical dust concentration from nine models compared for two dust periods over East Asia by Uno et al. [2006]. For subregions within East Asia the range is about 1 order of magnitude. It seems, therefore, that the current degree of uncertainty of dust models in regional studies over relatively short periods of days to weeks may be about 1 order of magnitude. This is somewhat greater than the uncertainty associated with model estimates of long-term mean global dust emission [Zender et al., 2004], suggesting that model over and underestimation in various regions may cancel out to a certain degree. All the models here have been "calibrated" in previous studies to produce sensible results, usually with respect to satellite or surface based estimates of AOT. This calibration tends to be conducted at the larger subcontinental scale, over North Africa in most cases. Therefore, the degree of model divergence in this case study may be surprising, As such, it is logical to conclude from this paper that model divergence may increase at smaller space/timescales. The BoDEx case study provides a particularly rigorous test of model performance, especially 


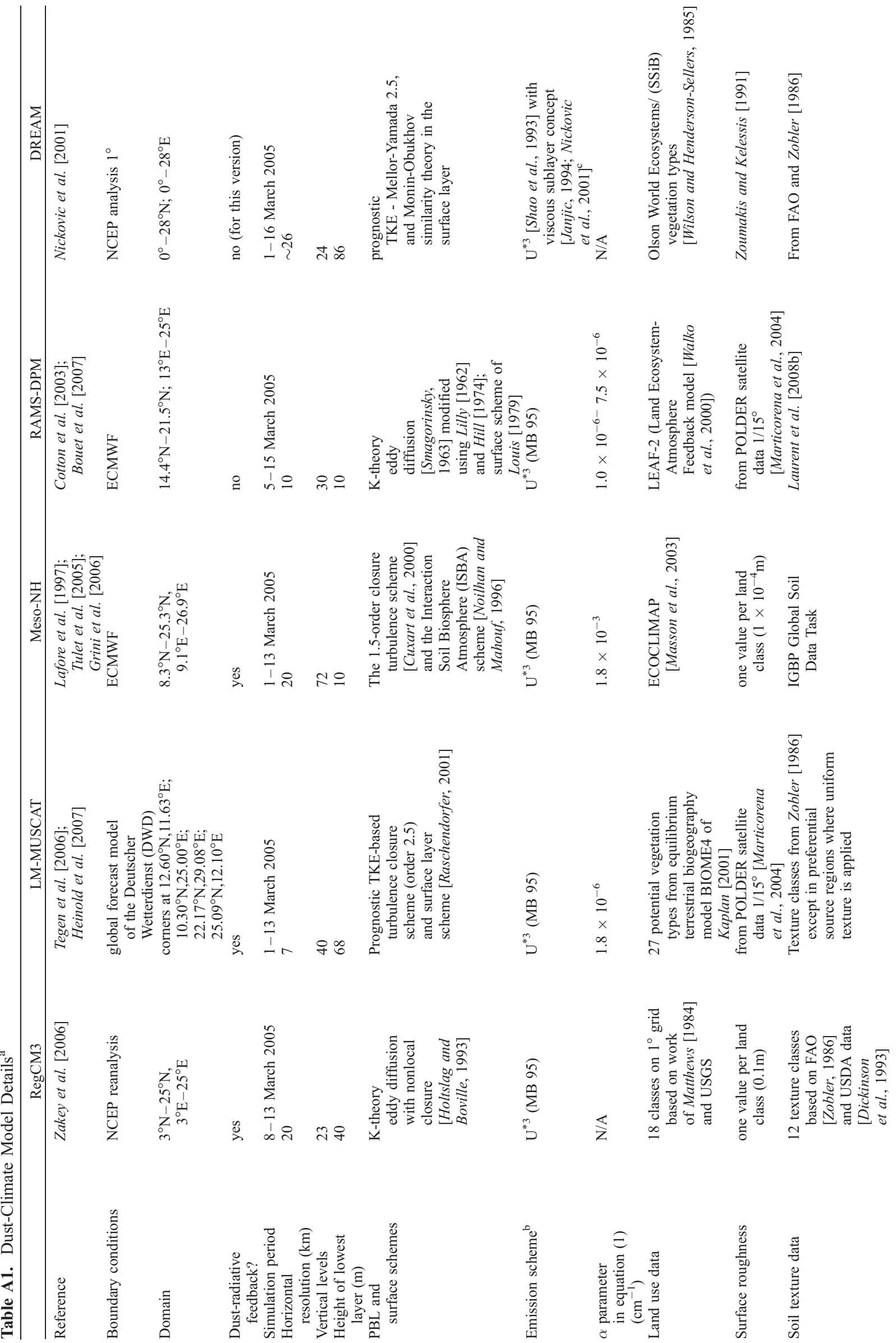




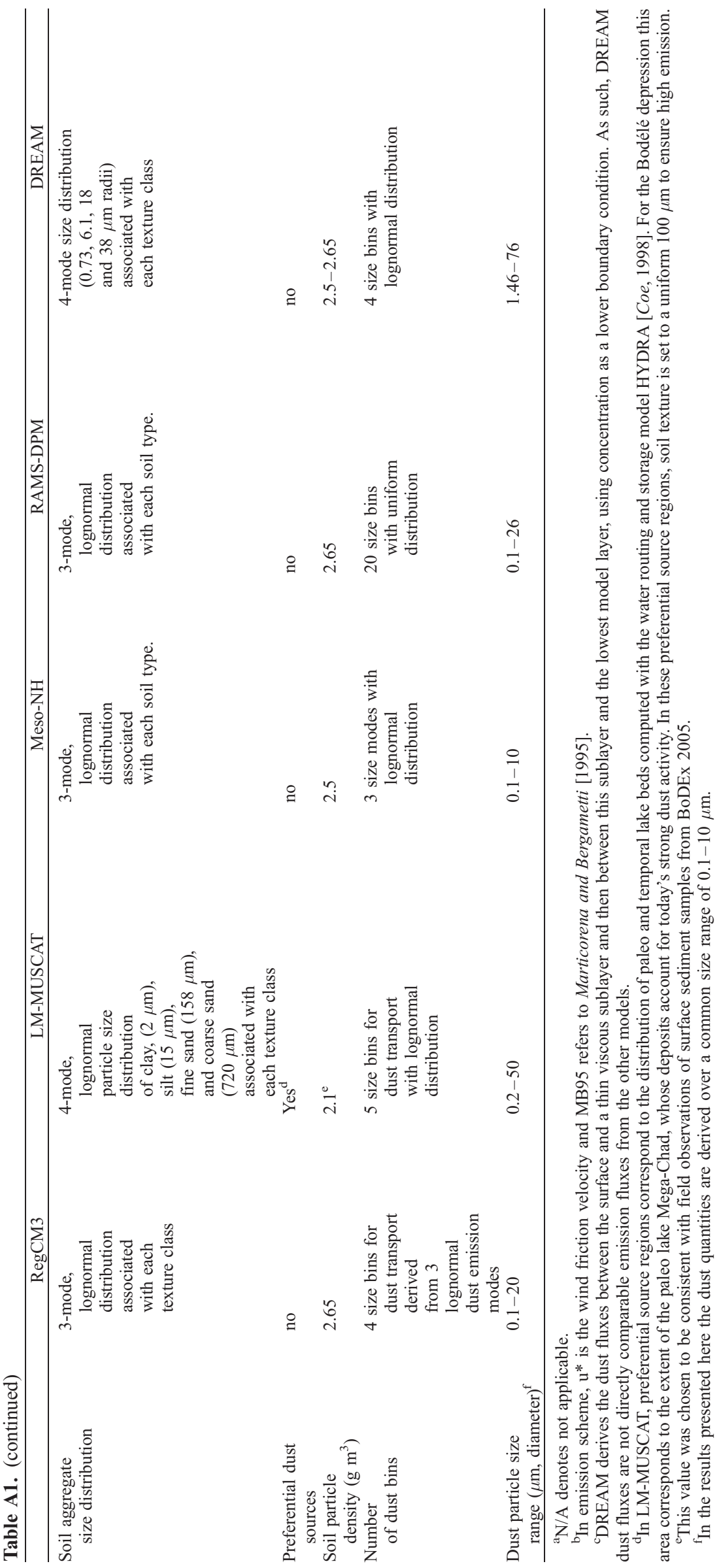

19 of 22 
given the particular soil and emission conditions in the region. The results highlight that model calibration which optimizes performance at larger scales may not be appropriate for specific regions.

[32] Further model intercomparison is necessary to determine the extent to which model divergence is associated with difference calibration of emission equation coefficients. In many cases, the model calibration or "tuning" is conducted by varying the $\alpha$ parameter in equation (1) such that model estimates of AOT are close to observations. This is not unreasonable since lack of accurate soil information means that direct application of the empirical relationship between clay fraction and $\alpha$ [Gillette, 1979] is problematic [Zender et al., 2003]. However, it should be noted that model simulations over the Sahara by Laurent et al. [2008b] in which $\alpha$ is derived from soil texture provide acceptable results. In any case, model "tuning" by varying the $\alpha$ parameter (or the $c$ constant in equation (2) for DREAM) to optimize model AOT represents a "catchall" correction which accounts for uncertainty in all aspects of the model, including meteorology, surface roughness, soil texture, emission size distribution and optical properties of the dust as well as the deposition schemes.

[33] Model intercomparison can be more useful to the research community when we are able to partition model error associated with various sources within the model. This process is hindered in the present study by differences in model configurations and model "tuning. "Thus, a future model intercomparison exercises should involve much more tightly constrained model configurations such that the sensitivity of model estimates to individual factors such as meteorological model performance, model resolution, boundary conditions, soil characteristics, dust physical and optical properties and the various parameterizations within the emission (and deposition) schemes can be quantified. This requires a coordinated set of multiple model experiments using a consistent set of predefined model configurations in which the domain, horizontal and vertical resolution, lateral boundary conditions, soil data, emission scheme coefficients, and aerosol size and optical properties are carefully defined.

[34] In addition, this program requires adequate observations for comparison. At present, the observational data on terms of dust emission, concentration, mass and flux are neither sufficiently accurate nor extensive enough in space and time to provide a suitable estimate of "truth" for absolute comparison with models. Therefore, the study highlights the pressing need for more comprehensive in situ observations in dust source regions like the Bodélé depression covering dust concentration, physical and optical properties of dust, as well and boundary layer meteorology, which are more extensive in space and time. Further detailed observations, perhaps using wind tunnel experiments, of the emission processes in the Bodéle are also required. Only when such data are available will we be able to really constrain model uncertainty and to identify individual sources of error. In the meantime, however, model experiments can comprehensively consider model sensitivity.

[35] Moreover, there is a clear need for further research into other source regions in the Sahara, and elsewhere. This should include identification of the key preferential dust source regions in the Sahara, observation of the dust emission processes and determination of the associated soil characteristics at a resolution higher than that available from existing soil data sets. While satellite-derived estimates of surface roughness are available [e.g., Marticorena et al., 2004] used here in LM-MUSCAT and RAMS-DPM dust models tend to rely on maps of soil texture (from which the dry soil size distribution is derived) with questionable accuracy in remote regions of the Sahara desert. There is a clear requirement for improved soil texture data for the Sahara that can resolve features like the diatomite deposits in the Bodélé depression. The results here demonstrate that the model dust emission is strongly associated with sandy soils such that the emission scheme itself may require modification in preferential source regions with similar characteristics to the Bodélé. It is important to determine to what extent the Bodélé is unusual among the source regions of the Sahara in this regard.

\section{Appendix A}

[36] This study involves a model intercomparison "of opportunity" such that the dust models have differing physics options and configurations. In Table A1 we provide details of the salient model features.

[37] Acknowledgments. The 'Deep Blue' satellite AOT from SeaWiFS data were kindly provided by Christina Hsu from NASA Goddard Space Flight Centre. Vanderlei Martins of the University of Maryland, processed the in situ dust concentration observations. We thank Didier Tanré and Jean-Louis Rajot for their effort in establishing and maintaining Aeronet Maine Soroa site. Thanks to Benoit Laurent for helpful comments.

\section{References}

Alfaro, S. C., and L. Gomes (2001), Modeling mineral aerosol production by wind erosion: Emission intensities and aerosol size distributions in source areas, J. Geophys. Res., 106(D16), 18,075-18,084, doi:10.1029/ 2000JD900339.

Blackadar, A. K. (1957), Boundary layer wind maxima and their significance for the growth of nocturnal inversions, Bull. Am. Meteorol. Soc., $38,283-290$.

Bouet, C., G. Cautenet, R. Washington, M. C. Todd, B. Laurent, B. Marticorena, and G. Bergametti (2007), Mesoscale modeling of aeolian dust emission during the BoDEx 2005 experiment, Geophys. Res. Lett., 34, L07812, doi:10.1029/2006GL029184.

Chamberlain, A. C. (1983), Roughness length of sea, sand and snow, Boundary Layer Meteorol., 25, 405-409, doi:10.1007/BF02041157.

Coe, M. T. (1998), A linked global model of terrestrial hydrologic processes: Simulation of modern rivers, lakes, and wetlands, J. Geophys. Res., 103(D8), 8885-8899, doi:10.1029/98JD00347.

Cotton, W. R., et al. (2003), RAMS 2001: Current status and future directions, Meteorol. Atmos. Phys., 82, 5-29, doi:10.1007/s00703-001-0584-9.

Cuxart, J., P. Bougeault, and J.-L. Redelsperger (2000), A turbulence scheme allowing for mesoscale and large eddy simulations, $Q$. J. $R$. Meteorol. Soc., 126, 1-30.

Dickinson, R. E., A. Henderson-Sellers, and P. J. Kennedy (1993), Biosphere-Atmosphere Transfer Scheme (BATS) version $1 \mathrm{E}$ as coupled to the NCAR Community Climate Model, NCAR/TN-387+STR, 72 pp., Natl. Cent. for Atmos. Res., Boulder, Colo.

Drake, N., and C. S. Bristow (2006), Shorelines in the Sahara: Geomorphological evidence for an enhanced monsoon from palaeolake Megachad, Holocene, 16, 901-911, doi:10.1191/0959683606hol981rr.

Forster, P. et al. (2007), Changes in atmospheric constituents and in radiative forcing, in Climate Change 2007: The Physical Science Basis. Contribution of Working Group I to the Fourth Assessment Report of the Intergovernmental Panel on Climate Change, edited by S. Solomon et al., pp. 129-234, Cambridge Univ. Press, Cambridge, U. K.

Gillette, D. A. (1979), Environmental factors affecting dust emission by wind erosion, in Saharan Dust, edited by C. Morales, pp. 71-94, John Wiley, Hoboken, N. J.

Goudie, A. S., and N. J. Middleton (1992), The changing frequency of dust storms through time, Clim. Change, 20, 197-225, doi:10.1007/ BF00139839. 
Grini, A., P. Tulet, and L. Gomes (2006), Dusty weather forecast using the Meso-NH mesoscale atmospheric model, J. Geophys. Res., 111, D19205, doi:10.1029/2005JD007007.

Hamilton, R. A., and J. W. Archibald (1945), Meteorology of Nigeria and adjacent territory, Q.J.R. Meteorol. Soc., 71, 231-262, doi:10.1002/ qj. 49707130905 .

Hastenrath, S. (1988), Climate and Circulation of the Tropics, Kluwer, Dordrecht, Netherlands.

Haywood, J. M., R. P. Allan, I. Culverwell, T. Slingo, S. Milton, J. Edwards, and N. Clerbaux (2005), Can desert dust explain the outgoing longwave radiation anomaly over the Sahara during July 2003?, J. Geophys. Res., 110, D05105, doi:10.1029/2004JD005232.

Heinold, B., J. Helmert, O. Hellmuth, R. Wolke, A. Ansmann, B. Marticorena, B. Laurent, and I. Tegen (2007), Regional modeling of Saharan dust events using LM-MUSCAT: Model description and case studies, J. Geophys. Res., 112, D11204, doi:10.1029/2006JD007443.

Herman, J. R., P. K. Bhartia, O. Torres, C. Hsu, C. Seftor, and E. Celarier (1997), Global distribution of UV-absorbing aerosols from Nimbus7/ TOMS data, J. Geophys. Res., 102(D14), 16,911-16,922, doi:10.1029/ 96JD03680.

Hill, G. E. (1974), Factors controlling the size and spacing of cumulus clouds as revealed by numerical experiments, J. Atmos. Sci., 31, 646673, doi:10.1175/1520-0469(1974)031<0646:FCTSAS > 2.0.CO;2.

Holben, B. N., et al. (1998), AERONET-A Federated Instrument Network and Data Archive for Aerosol Characterization, Remote Sens. Environ., 66, 1-16, doi:10.1016/S0034-4257(98)00031-5.

Holtslag, A. A. M., and B. A. Boville (1993), Local versus nonlocal boundary-layer diffusion in a global climate model, J. Clim., 6, 18251842, doi:10.1175/1520-0442(1993)006<1825:LVNBLD>2.0.CO;2.

Hsu, N. C., S. C. Tsay, M. D. King, and J. R. Herman (2004), Aerosol properties over bright-reflecting source regions, IEEE Trans. Geosci. Remote Sens., 42, 557-569, doi:10.1109/TGRS.2004.824067.

Janjic, Z. I. (1994), The step-mountain eta coordinate model: further developments of the convection, viscous sublayer and turbulence closure schemes, Mon. Weather Rev., 122, 927-945, doi:10.1175/15200493(1994)122<0927:TSMECM $>2.0$. CO;2

Kaplan, J. O. (2001), Geophysical applications of vegetation modeling, Ph.D. thesis, 113 pp., Dep. of Ecol., Lund Univ., Lund, Sweden.

Kinne, S., et al. (2003), Monthly averages of aerosol properties: A global comparison among models, satellite data, and AERONET ground data, J. Geophys. Res., 108(D20), 4634, doi:10.1029/2001JD001253.

Knippertz, P. (2008), Dust mobilization in the West African heat trough the role of the diurnal cycle and of extratropical synoptic disturbances, Meteorol. Z., 17, 553-563.

Koren, I., and Y. J. Kaufman (2004), Direct wind measurements of Saharan dust events from Terra and Aqua satellites, Geophys. Res. Lett., 31, L06122, doi:10.1029/2003GL019338.

Koren, I., Y. J. Kaufman, R. Washington, M. C. Todd, Y. Rudich, J. V. Martins, and D. Rosenfeld (2006), The Bodélé Depression: A single spot in the Sahara that provides most of the mineral dust to the Amazon forest, Environ. Res. Lett., 1, 014005, doi:10.1088/1748-9326/1/1/014005.

Lafore, J., et al. (1997), The Meso-NH Atmospheric Simulation System. Part I: adiabatic formulation and control simulations, Ann. Geophys., 16 , 90-109, doi:10.1007/s00585-997-0090-6

Laurent, B., B. Heinold, I. Tegen, C. Bouet, and G. Cautenet (2008a), Surface wind accuracy for modeling mineral dust emissions: Comparing two regional models in a Bodélé case study, Geophys. Res. Lett., 35, L09804, doi:10.1029/2008GL033654.

Laurent, B., B. Marticorena, G. Bergametti, J.-F. Léon, and N. M. Mahowald (2008b), Modeling mineral dust emissions from the Sahara desert using new surface properties and soil database, J. Geophys. Res., 113, D14218, doi:10.1029/2007JD009484.

Lilly, D. K. (1962), On the numerical simulation of buoyant convection, Tellus, 2, 148-172.

Louis, J. F. (1979), A parametric model of vertical eddy fluxes in the atmosphere, Boundary Layer Meteorol., 17, 187-202, doi:10.1007/ BF00117978.

Mahowald, N. M., M. Yoshioka, W. D. Collins, A. J. Conley, D. W. Fillmore, and D. B. Coleman (2006), Climate response and radiative forcing from mineral aerosols during the last glacial maximum, pre-industrial, current and doubled-carbon dioxide climates, Geophys. Res. Lett., 33, L20705, doi:10.1029/2006GL026126.

Marticorena, B., and G. Bergametti (1995), Modeling the atmospheric dust cycle: 1. Designed of a soil-derived dust emission scheme, J. Geophys Res., 100(D8), 16,415-16,430, doi:10.1029/95JD00690.

Marticorena, B., P. Chazette, G. Bergametti, F. Dulac, and M. Legrand (2004), Mapping the aerodynamic roughness length of desert surfaces from POLDER/ADEOS bi-directional reflectance product, Int. J. Remote Sens., 25, 603-626, doi:10.1080/0143116031000116976.
Masson, V., J.-L. Champeaux, F. Chauvin, C. Meriguet, and R. Lacaze (2003), A global database of land surface parameters at 1-km resolution in meteorological and climate models, J. Clim., 16, 1261-1282.

Matthews, E. (1984), Prescription of land-surface boundary conditions in GISS GCM II: A simple method based on high resolution vegetation data bases, Tech. Memo. 86096, 20 pp., NASA, Washington, D. C

May, P. T. (1995), The Australian nocturnal jet and diurnal variations of boundary-layer winds over Mt. Isa in north-eastern Australia, Q. J.R. Meteorol. Soc., 121, 987-1003.

Miller, R. L., and I. Tegen (1998), Climate response to soil dust aerosols, J. Clim., 11, 3247-3267, doi:10.1175/1520-0442(1998)011<3247: CRTSDA $>2.0 . \mathrm{CO} ; 2$

Morcrette, J.-J., L. Jones, J. Kaiser, A. Benedetti, and O. Boucher (2007), Toward a forecast of aerosols with the ECMWF Integrated Forecast System, ECMWF Newsl., 114, 15-17.

Nickovic, S., G. Kallos, A. Papadopoulos, and O. Kakaliagou (2001), A model for prediction of desert dust cycle in the atmosphere, J. Geophys. Res., 106(D16), 18,113-18,130, doi:10.1029/2000JD900794.

Noilhan, J., and J. Mahouf (1996), The ISBA land surface parametrisation scheme, Global Planet. Change, 13, 145-159, doi:10.1016/09218181(95)00043-7.

Parker, D. J., R. R. Burton, A. Diongue-Niang, R. J. Ellis, M. Felton, C. M. Taylor, C. D. Thorncroft, P. Bessemoulin, and A. M. Tompkins (2005), The diurnal cycle of the west African monsoon circulation, $Q . J . R$. Meteorol. Soc., 131, 2839-2860, doi:10.1256/qj.04.52.

Pérez, C., S. Nickovic, G. Pejanovic, J. M. Baldasano, and E. Özsoy (2006a), Interactive dust radiation modeling: A step to improve weather forecasts, J. Geophys. Res., 111, D16206, doi:10.1029/2005JD006717.

Pérez, C., S. Nickovic, J. M. Baldasano, M. Sicard, F. Rocadenbosch, and V. E. Cachorro (2006b), A long Saharan dust event over the western Mediterranean: Lidar, Sun photometer observations, and regional dust modeling, J. Geophys. Res., 111, D15214, doi:10.1029/2005JD006579.

Prospero, J. M., and P. J. Lamb (2003), African droughts and dust transport to the Caribbean: Climate change implication, Science, 302, 1024-1027, doi:10.1126/science. 1089915 .

Prospero, J. M., P. Ginoux, O. Torres, S. E. Nicholson, and T. E. Gill (2002), Environmental characterization of global sources of atmospheric soil dust identified with the Nimbus 7 Total Ozone Mapping Spectrometer (TOMS) absorbing aerosol product, Rev. Geophys., 40(1), 1002, doi:10.1029/2000RG000095.

Raschendorfer, M. (2001), The new turbulence parameterization of LM, COSMO Newsl., 1, 89-97.

Rodwell, M. J., and T. Jung (2008), Understanding the local and global impacts of model physics changes: An aerosol example, Q.J.R. Meteorol. Soc., 134, 1479-1497.

Segal, M. (1990), On the impact of thermal stability on some rough flow effects over mobile surfaces, Boundary Layer Meteorol., 52, 193-198, doi:10.1007/BF00123184

Shao, Y., M. R. Paupach, and P. A. Findlater (1993), Effect of saltation bombardment on the entrainment of dust by wind, J. Geophys. Res. 98(D7), 12,719-12,726, doi:10.1029/93JD00396.

Smagorinsky, J. (1963), General circulation experiments with the primitive equations. Part I. The basic experiment, Mon. Weather Rev., 91, 99-164, doi:10.1175/1520-0493(1963)091<0099:GCEWTP>2.3.CO;2.

Sultan, B., S. Janicot, and P. Dobrinski (2007), Characterisation of the diurnal cycle of the West African monsoon and monsoon onset, J. Clim., 20, 4014-4032, doi:10.1175/JCLI4218.1.

Tegen, I., P. Hollrig, M. Ching, I. Fung, D. Jacob, and J. Penner (1997), Contribution of different aerosol species to the global aerosol extinction optical thickness: Estimates from model results, J. Geophys. Res., 102(D20), 23,895-23,915, doi:10.1029/97JD01864.

Tegen, I., B. Heinold, M. C. Todd, J. Helmert, R. Washington, and O. Dubovik (2006), Modelling soil dust aerosol in the Bodélé Depression during the BoDEx campaign, Atmos. Chem. Phys., 6, 4345-4359.

Todd, M. C., R. Washington, J. V. Martins, O. Dubovik, G. Lizcano, S. M'Bainayel, and S. Engelstaedter (2007), Mineral dust emission from the Bodélé Depression, northern Chad, during BoDEx 2005, J. Geophys. Res., 112, D06207, doi:10.1029/2006JD007170.

Todd, M. C., R. Washington, S. Raghavan, G. Lizcano, and P. Knippertz (2008), Regional model simulations of the Bodélé low-level jet of northern Chad during the Bodélé Dust Experiment (BoDEx 2005), J. Clim. 21,995-1012, doi:10.1175/2007JCLI1766.1.

Torres, O., P. K. Bhartia, J. R. Herman, A. Sinyuk, P. Ginoux, and B. Holben (2002), A long-term record of aerosol optical depth from TOMS observations and comparison to AERONET measurements, J. Atmos. Sci., 59 , 398-413, doi:10.1175/1520-0469(2002)059<0398:ALTROA>2.0.CO;2. Tulet, P., V. Crassier, F. Cousin, K. Shure, and R. Rosset (2005), Orilam, a three moment lognormal aerosol scheme for mesoscale atmospheric model: On-line coupling into the Meso-NH-c model and validation on 
the ESCOMPTE campaign, J. Geophys. Res., 110, D18201, doi:10.1029/2004JD005716.

Uno, I., et al. (2006), Dust model intercomparison (DMIP) study over Asia: Overview, J. Geophys. Res., 111, D12213, doi:10.1029/2005JD006575.

Walko, R. L., et al. (2000), Coupled atmosphere-biophysics-hydrology models for environmental modeling, J. Appl. Meteorol., 39, 931-944, doi:10.1175/1520-0450(2000)039<0931:CABHMF $>2.0$. CO 2 .

Warren, A., A. Chappell, M. C. Todd, C. Bristow, N. Drake, S. Engelstaedter, V. Martins, S. M'Bainayel, and R. Washington (2007), Dust-raising in the dustiest place on Earth, Geomorphology, 92, 25-37, doi:10.1016 j.geomorph.2007.02.007.

Washington, R., and M. C. Todd (2005), Atmospheric controls on mineral dust emission from the Bodélé Depression, Chad: The role of the low level jet, Geophys. Res. Lett., 32, L17701, doi:10.1029/2005GL023597. Washington, R. W., M. C. Todd, N. Middleton, and A. S. Goudie (2003), Dust-storm source areas determined by the Total Ozone Monitoring Spectrometer and surface observations, Ann. Assoc. Am. Geogr., 93, 297-313, doi:10.1111/1467-8306.9302003.

Washington, R., M. C. Todd, S. Engelstaedter, S. Mbainayel, and F. Mitchell (2006), Dust and the low-level circulation over the Bodélé Depression, Chad: Observations from BoDEx 2005, J. Geophys. Res., 111, D03201, doi:10.1029/2005JD006502.

Wilson, M. F., and A. Henderson-Sellers (1985), Land cover and soils data sets for use in general circulation climate models, J. Climatol., 5, 119143, doi: $10.1002 /$ joc. 3370050202 .

Yoshioka, M., N. M. Mahowald, A. J. Conley, W. D. Collins, D. W. Fillmore, C. S. Zender, and D. B. Coleman (2007), Impact of desert dust radiative forcing on Sahel precipitation: Relative importance of dust compared to sea surface temperature variations, vegetation changes, and greenhouse gas warming, J. Clim., 20, 1445-1467, doi:10.1175/JCLI4056.1.

Zakey, A. S., F. Solmon, and F. Giorgi (2006), Implementation and testing of a desert module in a regional climate model, Atmos. Chem. Phys., 6, $4687-4704$.

Zender, C. S., H. Bian, and D. Newman (2003), Mineral Dust Entrainment And Deposition (DEAD) model: Description and 1990s climatology, J. Geophys. Res., 108(D14), 4416, doi:10.1029/2002JD002775.
Zender, C. S., R. L. Miller, and I. Tegen (2004), Quantifying mineral dust mass budgets: Terminology, constraints and current estimates, Eos Trans. $A G U, 85,509-512$, doi:10.1029/2004EO480002.

Zhang, J., and S. A. Christopher (2003), Longwave radiative forcing of Saharan dust aerosols estimated from MODIS, MISR, and CERES observations on Terra, Geophys. Res. Lett., 30(23), 2188, doi:10.1029/ 2003GL018479.

Zobler, L. (1986), A world soil file for global climate modelling, Tech. Meтo. 87802, 32 pp., NASA, Washington, D. C.

Zoumakis, N. M., and A. G. Kelessis (1991), The dependence of the bulk Richardson number on stability in the surface layer, Boundary Layer Meteorol., 57, 407-414, doi:10.1007/BF00120057.

J. M. Baldasano and C. Perez, Earth Sciences Department, Barcelona Supercomputing Center, Barcelona, E-08034 Spain. (Jose.baldasano@bsc.es; carlos.perez@bsc.es)

D. Bou Karam, Service d'Aéronomie, Institut Pierre-Simon Laplace, Université Pierre et Marie Curie, Paris, France. (diana@aero.jussieu.fr)

C. Bouet and G. Cautenet, Laboratoire de Météorologie Physique, Université Blaise Pascal, F-63170 Aubière, France. (bouet@lisa.univ-paris12. fr; G.Cautenet@opgc.univ-bpclermont.fr)

C. Cavazos and M. C. Todd, Department of Geography, University College London, Gower Street, London WC1E 6BT, UK. (ccavazos@geog. ucl.ac.uk;m.todd@geog.ucl.ac.uk)

B. Heinold and I. Tegen, Leibniz Institute for Tropospheric Research, D-04318 Leipzig, Germany. (heinold@mail.tropos.de; itegen@tropos.de)

I. Koren, Weizmann Institute, Rehovot 76100, Israel. (ilan.koren@ weizmann.ac.il)

F. Solmon, Laboratoire d' Aérologie, Université Paul Sabatier, F-31077 Toulouse, France. (Fabien.solmon@aero.obs-mip.fr)

P. Tulet, GMEI, CNRM, Météo France, F-31057 Toulouse, France. (Pierre.Tulet@meteo.fr)

R. Washington, Oxford Centre for the Environment, University of Oxford, Oxford OX1 3QY, UK. (Richard.washington@geog.ox.ac.uk)

A. Zakey, Abdus Salam International Centre for Theoretical Physics, I-34014 Trieste, Italy. (azakey@ictp.it) 